Baliatsas, C., Kamp, I. van, Bolte, J., Schipper, M., Yzermans, J., Lebret, E. Non-specific physical sympton's and electromagnetic field exposure in the general population: can we get more specific? A systematic revien Environment International: 2012, 41(1), 15-28

\begin{tabular}{|l|l|}
\hline Postprint Version & 1.0 \\
\hline Journal website & $\underline{\text { http://www.sciencedirect.com/science/article/pii/S0160412011002807 }}$ \\
\hline Pubmed link & $\underline{\text { http://www.ncbi.nlm.nih.gov/pubmed/22245541 }}$ \\
\hline DOI & $10.1016 /$ j.envint.2011.12.002 \\
\hline
\end{tabular}

This is a NIVEL certified Post Print, more info at http://www.nivel.eu

\title{
Non-specific physical symptoms and electromagnetic field exposure in the general population: Can we get more specific? A systematic review
}

\author{
CHRistos BALIATSAS ${ }^{\text {A,B }}$, , IRENE VAN KAMP ${ }^{\mathrm{B}}$, JOHN BOLTE $^{\mathrm{B}}$, MAARTEN SCHIPPER ${ }^{\mathrm{B}}$, JORIS YZERMANS ${ }^{\mathrm{C}}$, \\ ERIK LEBRET ${ }^{\mathrm{A}, \mathrm{B}}$. \\ a Institute for Risk Assessment Sciences, Utrecht University, Utrecht, The Netherlands. \\ ${ }^{\mathrm{b}}$ National Institute for Public Health and the Environment (RIVM), Bilthoven, The Netherlands. \\ ${ }^{c}$ Netherlands Institute for Health Services Research (NIVEL), Utrecht, The Netherlands.
}

\section{A B S T R A C T.}

Objective: A systematic review of observational studies was performed to address the strength of evidence for an association between actual and perceived exposure to electromagnetic fields (EMF) and non-specific physical symptoms (NSPS) in the general population. To gain more insight into the magnitude of a possible association, meta-analyses were conducted.

Methods: Literature databases Medline, Embase, SciSearch, PsychInfo, Psyndex and Biosis and additional bibliographic sources such as reference sections of key publications were searched for the detection of studies published between January 2000 and April 2011.

Results: Twenty-two studies met our inclusion criteria. Qualitative assessment of the epidemiological evidence showed either no association between symptoms and higher EMF exposure or contradictory results.

To strengthen our conclusions, random effects meta-analyses were performed, which produced the following results for the association with actual EMF; for symptom severity: Headache odds ratio $(\mathrm{OR})=1.65 ; 95 \%$ confidence interval $(\mathrm{CI})=0.88-3.08$, concentration problems $\mathrm{OR}=1.28 ; 95 \% \mathrm{CI}=0.56-2.94$, fatigue-related problems $\mathrm{OR}=1.15 ; 95 \% \mathrm{CI}=0.59$ 2.27, dizziness-related problems $\mathrm{OR}=1.38 ; 95 \% \mathrm{CI}=0.92-2.07$. For symptom frequency: headache $\mathrm{OR}=1.01 ; 95 \% \mathrm{CI}=0.66-1.53$, fatigue $\mathrm{OR}=1.12 ; 95 \% \mathrm{CI}=0.60-2.07$ and sleep problems $\mathrm{OR}=1.18 ; 95 \% \mathrm{CI}=0.80-1.74$. Associations between perceived exposure and NSPS were more consistently observed but a meta-analysis was not performed due to considerable heterogeneity between the studies.

Conclusions: This systematic review and meta-analysis finds no evidence for a direct association between frequency and severity of NSPS and higher levels of EMF exposure. An association with perceived exposure seems to exist, but evidence is still limited because of differences in conceptualization and assessment methods. 


\section{INTRODUCTION.}

Ongoing environmental exposures related to technological development such as air pollution, toxic substances and radiation give rise to people's worries about possible impact on health (Petrie et al., 2001). A part of the general population has concerns about potentially harmful effects from electromagnetic fields (EMF) emitted either by sources of near-field exposure such as mobile phones or from far-field exposure sources such as base stations for mobile telecommunication and high-voltage overhead powerlines (Blettner et al., 2009; Hutter et al., 2004; Schreier et al., 2006); in the latter case, exposure is often continuous and people perceive it as less controllable (Schreier et al., 2006). Not only concerns about increased risk for long-term conditions such as cancer are reported, but also a variety of symptoms without a clear pathological basis is attributed to relatively low-level exposure to EMF, such as redness, tingling and burning sensations (in the facial area), fatigue, tiredness, lack of concentration, dizziness, nausea, heart palpitation and digestive disturbances (Mild et al., 2006; WHO, 2005). The estimated prevalence of these nonspecific physical symptoms (NSPS) ranges between 3.5\% and 10\% (Blettner et al., 2009; Schreier et al., 2006; Schrottner and Leitgeb, 2008).

Although evidence that could support a causal association between exposure and outcome seems to be insufficient and inconsistent (Röösli and Hug, 2011; Röösli et al., 2010; Rubin et al., 2009), a possible effect of higher exposure levels cannot be ruled out yet because of methodological obstacles, primarily regarding bias related to exposure assessment and study design (Röösli, 2008; Röösli et al., 2010). Systematic reviews focusing mainly on experimental evidence suggest rather a nocebo effect which could imply an underlying psychological mechanism that leads to physiological responses and subsequent symptoms (Rubin et al., 2009). Therefore, perceived/ self-reported exposure, even poorly correlated with actual exposure levels (Inyang et al., 2008; Vrijheid et al., 2009) could be an important factor to investigate, since it is associated with NSPS (Baliatsas et al., 2011) and might have a distinct role in symptom report via concerns about possible health effects caused by EMF (Röösli, 2008).

Despite the fact that the vast majority of EMF research focuses on possible associations with chronic medical conditions such as leukemia and glioma, during the last years the international scientific literature on EMF and NSPS has grown, both with respect to objectively measured and self-reported exposure. In order to elucidate the pathways that lead to the report of EMF-related NSPS it is necessary to systematically examine these two aspects of exposure.

Observational studies are highly important due to the investigation of long-term exposure and effects in large population samples. Taking into consideration the methodological obstacles that epidemiological research on EMF and health is confronted with, important conclusions can be drawn from comprehensive reviews and meta-analyses rather than from a single study, as has been recently highlighted by Rothman (2009).

No systematic review has been conducted yet concentrating exclusively on observational studies on various sources of general population exposure to EMF and NSPS, assessing the existing evidence in terms of both actual and perceived exposure. In addition, no metaanalysis has been performed in the past on epidemiological data on EMF and NSPS.

The present paper attempts to identify the relevant observational epidemiological studies conducted in the last eleven years (2000-2011), in order to systematically assess the strength of evidence for an association between objectively measured (actual) and self-reported (perceived) exposure to EMF and NSPS.

\section{METHODS.}

\subsection{Data sources and searches.}

The following electronic databases were searched to detect relevant studies that were published between January 2000 and April 2011: Medline (US National Library of Medicine, Bethesda, Maryland), Embase (Elsevier B.V., Amsterdam, The Netherlands), SciSearch (Institute for Scientific Information, The Thomson Corporation, Stamford, Connecticut), PsychInfo (American Psychological Association, Washington, DC), Psyndex (German Institute of Medical Documentation and Information, Cologne, 
Germany) and Biosis (The Thomson Corporation, Stamford, Connecticut). There was no language restriction.

A wide range of keywords was used, related to EMF exposure and symptoms, which is presented in Table 1. In addition to the electronic database searches, the reference sections of previous systematic reviews, key papers, international reports on EMF and health and research databases of websites focused on the issue of EMF such as the "EMF Portal" and the WHO webpage were checked for potentially relevant articles.

\subsection{Inclusion criteria.}

For paper selection, four criteria were used:

I. An exposure criterion. Only studies examining symptom report in relation to general population exposure to radio-frequency (RF) EMF which did not exceed the levels established by the International Commission of Non-ionizing Radiation (ICNIRP) (1998) were considered as eligible for the review, covering a wide range of frequencies such as GSM, UMTS, FM radio, TDAB, WiMAX/LTE, analog TV and DVB-T, TETRA, DECT and WLAN/WIFI. The exposure could be either actual/objectively measured when an indicator of actual exposure levels was assessed (e.g. field strength), or perceived/self-reported when it was assessed by self-reported instruments. Studies on occupational exposure are not covered in this review.

II. A symptom report criterion. Studies should examine a range of self-reported physical/somatic symptoms without a diagnosed pathological or psychopathological cause. Since this review focuses on somatic symptoms as an outcome, results regarding mental health outcomes (e.g. depression) that are possibly presented by some of the reviewed studies are not included.Studies focusing on a possible association between EMF and chronic medical conditions (e.g. cancer) were also excluded. Moreover, studies focusing exclusively on ergonomic problems (such as musculoskeletal symptoms related to posture of computer users) are not covered in this paper.

III. A population criterion. The eligible studies recruited samples of healthy individuals being at least 12 years old. Studies focusing only on individuals with self-reported idiopathic environmental intolerance attributed to EMF (IEI-EMF) were not included.

IV. A study criterion. Only primary observational studies (not reanalyses, conference presentations or reviews) from the peer-reviewed literature, investigating a potential exposure- response relationship (and not being restricted to descriptive analyses) were considered as suitable for inclusion. The term "observational" refers to non-experimental studies such as cross-sectional, case control and cohort studies, in which the possible association between EMF and NSPS was investigated without an attempt to affect the exposure or the outcome. In the case of so-called "natural experiments" which combine both experimental and observational design, only the baseline results were included (if given). Case (individual) studies were excluded.

\section{[TABLE 1].}

\subsection{Evaluation of the quality of information}

The adequacy of the information provided in the articles was assessed based on the "Strengthening the Reporting of Observational Studies in Epidemiology (STROBE)" statement (Vol Elm et al., 2007). Minimal quality criteria were:

a) Provision of adequate information regarding study design, sample size, recruitment and characteristics.

b) Clear description of the methods that were followed for the assessment of the exposure and outcome.

c) Provision of adequate information regarding the performed statistical analyses including confounding adjustment (which should be at least for age and gender).

In case a selected article did not meet the forenamed basic criteria, further information was requested from the original authors. If there was no response, the article was excluded.

\subsection{Procedure}


For each included study, the following data were abstracted: references, study design, respondents' characteristics (including selection, sample size, response rate, age range or mean, gender distribution and country), exposure source and intensity recalculated in volts per meter $(\mathrm{V} / \mathrm{m})$, exposure assessment, outcome assessment, variables included as potential confounders and statistically significant associations between exposure and outcomes (Tables 2 and 3 ).

The literature search, evaluation of inclusion and exclusion criteria and evaluation of the quality of information in the articles were conducted by the first two authors, with uncertainties resolved through consultation with the rest of the co-authors.

More specifically, in the first stage the titles and abstracts that were derived from the search process were independently screened, to evaluate whether they met the exposure and symptom criteria.

The abstracts or titles were examined. Next, the hard copies of the publications fulfilling the inclusion criteria were assessed in terms of the population and study criteria. Finally, an article quality evaluation was performed.

\subsection{Data synthesis and analysis}

After paper selection and data extraction, the included studies were screened for meta-analysis suitability. Studies were considered eligible if they assessed the same symptoms, or outcomes of similar meaning (e.g. fatigue and exhaustion), employed comparable methods to assess exposure and used comparable instruments and cut-off points to assess the outcome(s). Based on these parameters, it was decided to conduct meta-analyses on the effect of objectively measured electromagnetic field strength on different NSPS. The risk of bias due to exposure misclassification, selective participation and confounding was assessed for the relevant studies (Table 4), as proposed by Grimes and Schulz (2002). Studies with a high risk of one or more of the basic categories of bias were not included in the meta-analyses; the method of rating was broadly based on schemes used by previous systematic reviews (Röösli et al., 2010). Finally, studies were included only if the adjusted odds ratios (OR) (risk for reference exposure category versus risk for highest exposed category) and 95\% confidence interval (95\% CI) for the association were given or derivable.

Studies were grouped on the basis of the investigated symptoms and assessment (frequency/chronicity or severity/acuteness). For each reported outcome the log-transformed OR value and standard error were calculated. Effect sizes were weighted using the inverse variance method (Sutton et al., 2000).

DerSimonian-Laird random effects meta-analyses (DerSimonian and Laird, 1986) were performed to calculate the pooled OR estimates and their $95 \%$ CI. Two measures of heterogeneity were used: The Squared tau $\left(\tau^{2}\right)$ value which indicates the underlying betweenstudy variability (Rücker et al., 2008) and the $\mathrm{I}^{2}$ quantity which describes the percent variation across studies due to heterogeneity rather than chance (Higgins et al., 2003); low, moderate and high heterogeneity levels correspond to $\mathrm{I}^{2}$ values of $25 \%, 50 \%$ and $75 \%$ respectively.

Publication bias was assessed by Egger's regression test (level of significance: pb0.05) (Egger et al., 1997). Where possible, we also performed a number of sensitivity analyses to evaluate the stability of the results. Meta-analyses were performed using the MIX software version 1.7 (Bax et al., 2006).

\subsection{Definitions}

In the present paper, three main terms are consistently used to describe the exposure and outcome: Actual EMF Exposure, Perceived EMF Exposure and Non-specific Physical Symptoms (NSPS).

Actual Exposure refers to EMF levels assessed by objective exposure indicators/proxies such as measurements of field strength. Perceived Exposure is determined as the subjective estimation of the magnitude of being exposed to EMF (sources), assessed by selfreported instruments. In this review, perceived exposure is investigated as an indicator of a nocebo effect and not as a proxy for actual exposure. NSPS refers to the health outcomes, as a general and neutral term which does not imply any causal link with a particular pathogenic source.

\section{RESULTS}

\subsection{Study characteristics}


The database investigation yielded 640 abstracts in total: 400 from Medline and 240 from the other 5 electronic databases. The citations that were derived from Medline were complete including both title and abstract, while only the title was available for a considerable amount of citations in the other databases. Whenever necessary, we sought for further information by requesting the full articles. Overall, 608 studies were excluded, because they did not meet the inclusion criteria (Fig. 1). A further search in additional bibliographic sources yielded 9 studies, which all appeared to be eligible. Forty-one articles were found to be eligible for the review; evaluation with regards to article quality of reporting led to a further exclusion of 21 studies (Appendix A). Finally, 20 research articles from the peer-reviewed literature were accepted for this review, representing 22 studies (Tables 2 and 3); eighteen of cross-sectional design, three longitudinal and one case-control study.

Ten studies investigated NSPS in relation to actual exposure, 9 studies on perceived exposure and 3 studied both aspects. Response rates were given in 17 studies, ranging from $37 \%$ to $88 \%$ for the studies on actual exposure and from $36 \%$ to $75 \%$ for the studies on perceived exposure. Sample sizes ranged between 54 420095 (actual exposure studies) and 132-4520 subjects (perceived exposure studies). The percentage of female participants ranged between $15 \%-66 \%$ and $10 \%-66 \%$ respectively.

Inmost of the studies on actual exposure,mobile phone base stations constituted the EMF source of primary concern in the investigation ( $\mathrm{n}=8)$, whilemost of the studies providing data on the effect of perceived exposure on NSPS, focused on mobile/wireless phone use $(\mathrm{n}=9)$. The majority of the studies was conducted in Europe $(n=20)$.

\subsection{Actual exposure and NSPS}

Thirteen studies in total provided data on the association between actual exposure and NSPS; eleven of cross-sectional design, one longitudinal study and one registrybased cohort (Table 2). Exposure ( $24 \mathrm{~h})$ assessment was based on field strength spot measurements ( $\mathrm{n}=7$ studies), use of personal dosimeters during waking hours $(n=4)$, exposure prediction modeling $(n=1)$ and geo-coded distance to base stations $(n=1)$. The time weighted average electric field strength in these studies could be approximately estimated as $\leq 0.1$ $\mathrm{V} / \mathrm{m}$ for the reference (low/unexposed) group of participants and did not exceed the $5 \mathrm{~V} / \mathrm{m}$ for the individuals being considered as highly exposed.

Eight studies used standardized instruments to assess NSPS (Altpeter et al., 2006; Berg-Beckhoff et al., 2009; Blettner et al., 2009; Heinrich et al., 2010; Heinrich et al., 2011; Hutter et al., 2006; Mohler et al., 2010; Thomas et al., 2008). The "Von Zerssen complaint list" (Von Zerssen, 1976) was the most consistently used symptom scale.

Overall, the most frequently investigated outcomes were headache, sleep problems, dizziness-related symptoms (such as vertigo), fatigue-related symptoms (such as exhaustion) and concentration problems. The majority of the studies did not show a significant effect of exposure on fatigue related-symptoms $(\mathrm{n}=4$ versus $n=1$ ) and concentration difficulties ( $n=3$ versus $n=1$ ).

Findings for headache were contradictory, since $n=4$ studies reported a significant association with higher exposure levels, while $n=3$ suggested no association. Results for sleep problems and dizziness-related symptoms were also found to be contradictory ( $n=4$ versus $n=5$ and $n=3$ versus $n=3$ respectively). Two studies used symptom total scores as outcome (Berg-Beckhoff et al., 2009; Blettner et al., 2009); one did not find any exposure effect while the other showed a weak association, although only geo-coded distance to base stations was employed (Blettner et al., 2009), which is a not a sufficient proxy for actual exposure (Frei et al., 2010).

Evidence regarding other NSPS (e.g. migraine and memory problems) was limited and inconsistent. Studies employing more advanced exposure characterization methods such as personal dosimeters and exposure prediction modeling were less likely to find significant associations (Heinrich et al., 2010, 2011; Mohler et al., 2010; Thomas et al., 2008). Apart from age, gender and socio-economic status, the most examined potential confounders were perceived mobile phone use, urbanization level, smoking habits and risk perception/concerns related to possible health effects caused by EMF exposure. It should be mentioned that although the studies of Heinrich et al. $(2010,2011)$ and Milde-Busch et al. (2010) investigate different outcomes (e.g. acute versus chronic symptoms), they are based on the same sample. 
[TABLE 2-3-4].

\subsection{Perceived exposure and NSPS}

Twelve studies provided data on the association between perceived exposure and NSPS; ten of crosssectional design, one case-control study and one cohort (Table 3).

Perceived exposure was measured based mainly on the daily mobile phone use.

Seven studies used standardized instruments to assess symptoms (Heinrich et al., 2010, 2011; Herr et al., 2005; Hutter et al., 2010; Milde-Busch et al., 2010; Mohler et al., 2010; Thomée et al., 2011). The most consistently examined outcomes were headache, dizziness, sleep problems, fatigue-related symptoms, concentration problems, burning sensations in the facial area, ears or body and tinnitus. Most of the studies showed an effect of perceived exposure on concentration problems $(n=4$ versus $n=2)$ and headache $(n=5$ versus $n=3$ ), while no statistically significant effect was demonstrated for the majority of the studies on sleep problems ( $n=4$ versus $n=1)$ and dizziness ( $n=5$ versus $n=2$ ).

\section{[FIGURE 1].}

Results were contradictory for fatigue-related symptoms ( $\mathrm{n}=4$ studies reported significant associations versus $n=3$ that did not report significant results), tinnitus ( $n=2$ versus $n=1)$ and burning sensations $(n=2$ versus $n=2$ ). Again, evidence regarding other NSPS was limited and inconsistent. Apart from age, gender and socioeconomic status, there was a quite consistent adjustment for video display terminal (VDT) use, stress-related variables and urbanization level as potential confounders.

\subsection{Meta-analyses}

Overall, 5 studies were excluded from the meta-analyses (Abdel-Rassoul et al., 2006; Abelin et al., 2006; Altpeter et al., 2006; Blettner et al., 2009; Preece et al., 2007), primarily due to high risk for bias and lack of comparability. One study was excluded because it was not possible to obtain the OR and $95 \%$ CI (BergBeckhoff et al., 2009). Finally, depending on the outcome, 2 to 4 studies of cross-sectional design were included in the meta-analyses (Heinrich et al., 2010, 2011; Hutter et al., 2006; Mohler et al., 2010; Thomas et al., 2008) (Table 5). Most of the studies characterized exposure levels using personal dosimeters (Heinrich et al., 2010, 2011; Thomas et al., 2008). The investigated NSPS were headache, concentration problems, fatiguerelated problems, dizziness-related problems and sleep problems. Since studies used selfreported scales to measure either the frequency of symptoms (labeled as "chronic") or severity (labeled as "acute"), apart from the classification of the studies on the basis of the investigated symptom, they were also grouped based on these types of measures in order to enhance their comparability. All the "acute" NSPS were measured with items from the "Von Zerssen complaint list" (Von Zerssen, 1976). Among the 3 studies assessing these symptoms (Heinrich et al., 2010; Hutter et al., 2006; Thomas et al., 2008), two used the same cut-off points (Heinrich et al., 2010; Hutter et al., 2006); a symptom was considered to be present if it was "at least of weak intensity", while in the study of Thomas et al. (2008) if it was "at least moderate". Regarding the "chronic" NSPS, although the two eligible studies (Heinrich et al., 2011; Thomas et al., 2008) employed different standardized scales (Fahrenberg, 1975; Haugland and Wold, 2001) they used similar cut-off points (a symptom was considered to be present if occurred "nearly once every week" and "at least twice a month" respectively) and the same time reference ("during the last six months"). For the assessment of sleep problems, most of the analyzed studies used summarized items on sleep quality (Hutter et al., 2006; Mohler et al., 2010; Thomas et al., 2008).

In the study of Hutter et al. (2006) a median split was applied for the total score of sleep quality (OR and $95 \%$ CI were available after personal communication with the original authors). In the study of Mohler et al. (2010) a number of questions about subjective sleep quality were summarized into a binary sleep quality score (ranging between 0 and 12); a score of $\leq 8$ was considered as an indication of having sleep problems. The time reference for these two studies was "during the last month" and "during the last four months" respectively. The scales and cut-off points for the studies of Thomas et al. (2008) and Heinrich et al. (2011) were the same as for the measurement of "chronic" NSPS which were previously described. There were between 919 and 1897 study participants included in each analysis. 
The publication dates of the studies included ranged between 2006 and 2011. The forest plots for summarizing the meta-analyses for the 7 outcomes are shown in Figs. 2 and 3. Heterogeneity was negligible to moderate for the NSPS that were measured based on their severity (acute) and negligible to low for the NSPS that their assessment was based on their frequency (chronic). There was no publication bias apparent.

Analyses did not show a significant effect of higher exposure levels on any of the examined outcomes (Table 5, Figs. 2 and 3).

Two of the analyzed studies on acute NSPS investigated symptom report in relation to exposure during both morning and afternoon hours (Heinrich et al., 2010; Thomas et al., 2008); since in the abovementioned meta-analyses we used the ORs for symptoms occurring during morning hours, additional analyses were performed replacing these ORs with the ones for symptoms reported in the afternoon. Statistically significant results were observed for headache $(\mathrm{OR}=1.9 ; 95 \% \mathrm{CI}=1.07-3.49, \mathrm{p}=0.03)$ and dizziness-related problems $(\mathrm{OR}=1.54 ; 95 \% \mathrm{CI}=1.02-2.31, \mathrm{p}=0.04)$, while the risk estimate for the rest of the acute outcomes remained non-significant (concentration problems: $\mathrm{OR}=1.4 ; 95 \% \mathrm{CI}=0.81-2.41, \mathrm{p}=0.22$, fatigue-related problems: $\mathrm{OR}=0.92 ; 95 \% \mathrm{CI}=0.48-1.77, \mathrm{p}=0.82$ ).

An extra sensitivity analysis was performed by integrating the OR of the studies excluded from the metaanalyses (based on the quality and comparability criteria) into the principal analyses. This was possible for 2 studies assessing headache based on its frequency (Abdel-Rassoul et al., 2006; Preece et al., 2007) and 2 assessing sleep problems (Abdel-Rassoul et al., 2006; Abelin et al., 2006); the recalculated pooled estimate remained non-significant for chronic headache $(\mathrm{OR}=2.03 ; 95 \% \mathrm{CI}=0.79-5.19, \mathrm{p}=0.14)$ and for sleep problems was $\mathrm{OR}=1.65 ; 95 \% \mathrm{CI}=1.00-2.72, \mathrm{p}=0.05$. In line with the qualitative evaluation, there were very high levels of statistical heterogeneity $\left(I^{2}=89 \%\right.$ and $\left.I^{2}=70 \%\right)$, which demonstrate the incomparability of these studies, since the exposure characterization methods, self-reported symptom scales and especially the cut-off points varied considerably.

\section{DISCUSSION}

The present systematic review identified the observational epidemiological studies conducted during the last eleven years on the effect of actual and perceived EMF exposure on the report of NSPS in the general population. Using sensitive search strategies and strict quality criteria, we distinguished the most examined NSPS and assessed the strength of evidence for an association with higher exposure levels. Meta-analyses were conducted to quantify the associations.

The review showed that there is no consistent association between actual exposure to EMF and occurrence of NSPS in the general population. Most of the studies suggested either no significant effect of higher exposure levels as in the case of fatigue-related symptoms and concentration difficulties, or contradictory results as in the case of dizziness-related symptoms, sleep problems and headache. It was also observed that methodological quality was an important component for the strength of the associations, since studies with a higher risk of bias, mainly regarding exposure assessment and sample selection, reported more significant associations.

More recent studies which tend to employ advanced exposure characterization methods did not suggest a significant effect; this is in agreement with the findings of Röösli and Hug (2011). Studies on perceived exposure showed generally stronger symptomatic effects and more consistent patterns, indicating an association with concentration problems and headache, while most of them yielded nonsignificant or contradictory results for sleep problems, dizziness, fatigue-related symptoms and tinnitus. Differences in the conceptual framework of perceived exposure and variation in symptom and exposure assessment prevented us from conducting a meta-analysis of these studies.

\section{[TABLE 5].}

Pooling the risk estimates of studies with a smaller chance of exposure misclassification and selection and confounding bias, the performed meta-analyses yielded no significant risk difference between low exposed and highly exposed individuals regarding symptom frequency and severity. In a sensitivity analysis of "acute" symptoms, when we pooled the ORs for exposure measurements "during afternoon hours" instead of exposure "during morning hours" for two of the studies, analyses yielded statistical significance only for headache and dizziness-related problems. This is probably due to the nearly significant OR in the study 
with the most power (Heinrich et al., 2010). Since this was the case for a number of associations in that study, the authors attributed it to multiple testing, stating that after considering exposure as a $90 \%$ cut-off in the analyses (data were not available), any significant association disappeared.

It is notable that while 9 out of 13 reviewed studies on actual exposure data suggest an association for at least one symptom, when we qualitatively examined these associations per symptom group, only the effect on headache was slightly more often significant. In this qualitative assessment we did not exclude studies of higher chance of bias which are prone to effect overestimation. In the meta-analysis, where those studies were excluded, all the associations were found to be non-significant. Since quality assessment in metaanalysis is often controversial, in an additional sensitivity analysis we pooled the risk ratio of studies with higher probability of bias in the principal analyses; the summary effect was higher but heterogeneity was striking. Despite the non-significant results, it is noteworthy that the vastmajority of the exposure-symptom associations in the studies on actual exposure show a positive association. Independently of the study quality, exposure and outcome measures and examined symptoms, people who are exposed to higher levels of EMF, tend to report NSPS more frequently or severely than their "unexposed" counterpart. Possible explanations for this phenomenon could be just chance, selection bias leading to overestimation of the effect, positive-outcome bias in peerreview literature (Emerson et al., 2010), the lack of sufficient exposure contrast which could mask an exposure-outcome association if one existed, or the small prevalence in the general population of people sensitive to EMF, which could reduce the power for the detection of a significant effect. Additionally, possible exposure misclassification effects cannot be dismissed due to the existing limitations in exposure characterization (Röösli and Hug, 2011).

\section{[FIGURE 2-3].}

The strengths of this systematic review include a comprehensive search strategy, the examination of studies on both actual and perceived exposure and the performance of meta-analyses. Important publication bias as a result of preferential publication of studies with significant findings is unlikely to have occurred as Eggers's test on bias also indicated. However, in some cases Egger's test could not calculate the bias risk due to the limited number of studies. Among the articles excluded due to inadequacy of the provided information and lack of minimal confounding adjustment, only one concerned actual exposure, suggesting a positive significant association with various NSPS (Eger and Jahn, 2010). All the other excluded studies focused on perceived exposure, with the vast majority reporting a significant effect, which was not adjusted for confounders (Appendix A).

This is the first time that a meta-analytic study is conducted for the effect of EMF on NSPS. The only formal meta-analysis to date in this research field focused on the individual ability to perceive short-term EMF exposure tested by randomized double-blind trials (Röösli, 2008; Röösli et al., 2010), including only a small number of studies. In the present meta-analyses, a considerable number of subjects were included, and all the analyzed studies were considered comparable in terms of study design, type of exposure source, exposure and outcome assessment. Although there was some variation in the measured exposure levels across the studies, they all were much lower than the safety limits as established by ICNIRP (1998). Our meta-analysis has a number of limitations, such as the small number of comparable studies available for analysis, which however reflects that there are only a few comparable high quality studies addressing this issue. This prevented us from performing a metaregression with other explanatory variables. Another shortcoming might be the fact that the study with the most statistical power was restricted to the age groups between 13 and 17 years old, which could constitute a source of heterogeneity. Nevertheless, epidemiological studies on actual exposure often set the 15 years of age or even lower as age limit for participation (Berg-Beckhoff et al., 2009; Blettner et al., 2009) and no important differences between adolescents and young adults have been shown in terms of symptom patterns, even for larger age contrasts (Yzermans and Oskam, 1990).

Finally, some between-study variation was expected due to the classification of symptoms in groups and a few differences in cut-off points as was described in detail in the Results section.

This review included studies on actual as well as perceived exposure to EMF. Since people are not able to accurately self-estimate the magnitude of personal exposure to EMF sources (Frei et al., 2010; Inyang et al., 2008; Vrijheid et al., 2009), we used perceived exposure as an indicator of a nocebo phenomenon that could possibly indicate underlying psychological processes. The subjective belief of being exposed to a hazardous environmental source could reinforce the alertness for the presence of potential exposure indicators, the 
expectations of symptom occurrence and consequently the development and report of symptoms (Landgrebe et al., 2008). In the broader literature a number of studies have accentuated the role of psychologically-oriented factors in the report of NSPS attributed to environmental exposures (Johansson et al., 2010; Landgrebe et al., 2008; Osterberg et al., 2007; Persson et al., 2008; Rubin et al., 2006, 2008).

However, most of the reviewed studies used perceived exposure as a proxy for actual exposure. This may explain the inconsistency across results. More recently published studies on actual exposure (Heinrich et al., 2010, 2011; Mohler et al., 2010) investigated the effect of perceived exposure as well, together with some psychological components such as environmental worries as confounders, but evidence regarding psychological determinants of NSPS related to EMF is still very limited and consensus about a conceptual framework on their mediating or moderating role is lacking.

Although, in terms of design, experimental studies are preferable for the clarification of causal relationships, observational studies allow the investigation of longer-term exposures and outcomes and evaluation of possible mediating determinants in larger population samples. Exposure assessment remains a major challenge. On the one hand, methods such as self reported exposure or geo-coded distance are not sufficient surrogates for personal exposure, and spot measurements provide only limited knowledge on exposure for specific locations (Frei et al., 2010). On the other hand, personal exposure measurements with exposimeters come with biases due to calibration issues, arrival angle dependent response, and body shielding, which lead to underestimation of the actual exposure (Bolte et al., 2011; Mann, 2010). Also, performing personal exposure measurements in large groups is very time consuming and expensive and therefore may not be feasible for large, especially cohort, studies.

Nevertheless, personal exposure measurements are recommended, as they are actually measuring one's exposure during all activities at all locations (Neubauer et al., 2007). If it is not feasible to measure every group member, a prediction model based on modeled exposure of fixed transmitters and exposimeter measurements may be the best compromise (Frei et al., 2009, 2010).

Since the restriction of sources of bias is of vital importance, future epidemiological studies should be particularly careful regarding the sample selection and data collection; the combination of electronic medical records from general practices and self-reported health data in conjunction with exposure data, would be an important step forward in this field of research. For future research, it is also suggested that instead of adopting either the psychogenic or the bioelectromagnetic hypothesis for the explanation of NSPS in relation to EMF, the exposure-outcome association should be considered as a product of an interaction between actual exposure, the perception of the magnitude of being exposed and psychological factors, consonant to a psychobiological approach.

In light of this systematic review, and taking findings from systematic evaluation of experimental evidence into account (Röösli and Hug, 2011; Röösli et al., 2010; Rubin et al., 2009) it is concluded that there is no direct association between actual exposure to EMF and NSPS. An association between NSPS and perceived exposure seems to be stronger and more consistent, but striking heterogeneity regarding the conceptual framework and assessment of exposure and outcome prevents from more solid conclusions. The establishment of an international protocol of harmonization of concepts and exposure-outcome characterization would minimize the methodological obstacles in epidemiological research on EMF and NSPS and strengthen the interpretations of future metaanalytic studies.

\section{CONCLUSIONS}

There are no indications for an association between higher levels of actual EMF exposure and frequency or severity of NSPS in the general population. An association with perceived exposure seems to exist, but evidence is still scarce mainly because of between-study differences in the conceptual framework and measurement. More epidemiological studies are needed, using comparable methods and instruments to assess exposure and outcome and investigating the role of perceived exposure and mediating psychological components in conjunction with actual exposure. Studies on long-term effects of residential EMF exposure are of particular importance in order to enhance our knowledge.

Funding source This work was supported by The Netherlands Organisation for Health Research and Development (ZonMw). This study is part of the Dutch project EMPHASIS "Non-specific physical symptoms in relation to actual and perceived exposure to EMF and the underlying mechanisms".

Conflict of interest statement None declared. 
Baliatsas, C., Kamp, I. van, Bolte, J., Schipper, M., Yzermans, J., Lebret, E. Non-specific physical symptomis and electromagnetic field exposure in the general population: can we get more specific? A systematic review Environment International: 2012, 41(1), 15-28

Acknowledgments The authors thank all investigators who kindly provided additional information from their studies. They would also like to thank Wim ten Have for his help with the development of the literature search strategy and search in the different databases and Dr. Rik Bogers and Dr. Anke Huss for their advice and general feedback on the paper.

\section{[APPENDIX ]}

\section{REFERENCES}

Abelin T, Altpeter E, Röösli M. Sleep disturbances in the vicinity of the short-wave broadcast transmitter Schwarzenburg. Somnologie 2005;9:203-9.

Abdel-Rassoul G, El-Fateh OA, Salem MA, Michael A, Farahat F, El-Batanouny M, Salem E. Neurobehavioral effects among inhabitants around mobile phone base stations. Neurotoxicology 2006;28:434-40.

Al-Abduljawad KA. Effects of the mobile phones on hearing function of the users. Bah Med Bull 2008;30:72-4.

Al-Khamees N. A study in Kuwait of health risks associated with using cell phones. Coll Stud J 2007;41:187-202.

Al Khamees $\mathrm{N}$. What message should health educators give regarding electromagnetic fields? Coll Stud J 2008;42:730-7.

Al-Khlaiwi T, Meo SA. Association of mobile phone radiation with fatigue, headache, dizziness, tension and sleep disturbance in Saudi population. Saudi Med J 2004;25:732-6.

Altpeter ES, Röösli M, Battaglia M, Pfluger D, Minder CE, Abelin T. Effect of short-wave (6-22 MHz) magnetic fields on sleep quality and melatonin cycle in humans: the Schwarzenburg shutdown study. Bioelectromagnetics 2006;27:142-50.

Augner C, Hacker GW. Are people living next to mobile phone base stations more strained relationship of health concerns, self-estimated distance to base station, and psychological parameters. Indian J Occup Environ Med 2009;13:141-5.

Baliatsas C, Van Kamp I, Kelfkens G, Schipper M, Bolte J, Yzermans J, Lebret E. Nonspecific physical symptoms in relation to actual and perceived proximity tomobile phone base stations and powerlines. BMC Public Health 2011;11:421.

Balikci K, Ozcan IC, Turgut-Balik D, Balik HH. A survey study on some neurological symptoms and sensations experienced by long term users of mobile phones. Pathol Biol 2005;53:30-4.

Balik HH, Tutgut-Balik D, Balikci K, Ozcan IC. Some ocular symptoms and sensations experienced by long term users of mobile phones. Pathol Biol 2005;53:88-91.

Bax L, Yu LM, Ikeda N, Tsuruta H, Moons KG. Development and validation of MIX: comprehensive free software for meta-analysis of causal research data. BMC Med Res Methodol 2006;6:50.

Berg-Beckhoff G, Blettner M, Kowall B, Breckenkamp J, Schlehofer B, Schmiedel S, Bornkessel C, Reis U, Potthoff $P$, Schüz J. Mobile phone base stations and adverse health effects: phase 2 of a cross-sectional studywithmeasured radio frequency electromagnetic fields. Occup Environ Med 2009;66:124-30.

Blettner M, Schlehofer B, Breckenkamp J, Kowall B, Schmiedel S, Reis U, Potthoff P, Schüz J, BergBeckhoff $\mathrm{G}$. Mobile phone base stations and adverse health effects: phase 1 of a population-based, cross-sectional study in Germany. Occup Environ Med 2009;66:118-23.

Bolte J, Van der Zande G, Kamer J. Calibration and uncertainties in personal exposure measurements of radiofrequency electromagnetic fields. Bioelectromagnetics 2011;32:652-63.

Buysse DJ, Reynolds CF, Monk TH, Berman SR, Kupfer DJ. The Pittsburgh Sleep Quality Index: a new instrument for psychiatric practice and research. Psychiatry Res 1989;28:193-213.

Chia SM, Chia HP, Tan JS. Prevalence of headache among handheld cellular telephone users in Singapore: a community study. Environ Health Perspect 2000;108:1059-62.

Davidson HC, Lutman ME. Survey of mobile phone use and their chronic effects on the hearing of a student population. Int J Audiol 2007;46:113-8.

DerSimonian R, Laird N. Meta-analysis in clinical trials. Control Clin Trials 1986;7: 177-88.

Eger H, Jahn M. Specific health symptoms and cell phone radiation in Selbitz (Bavaria, Germany) evidence of a dose response relationship.Umwelt-Medizin- Gesellschaft 2010;23:130-9.

Egger M, Smith GD, Phillips AN. Meta-analyses: principles and procedures. BMJ 1997;315:1533.

Emerson GB, Warme WJ, Wolf FM, Heckman JD, Brand RA, Leopold SS. Testing for the presence of positive-outcome bias in peer review. A randomized controlled trial. Arch Intern Med 2010;170(21):19349. 
Baliatsas, C., Kamp, I. van, Bolte, J., Schipper, M., Yzermans, J., Lebret, E. Non-specific physical sympton's and electromagnetic field exposure in the general population: can we get more specific? A systematic reviem Environment International: 2012, 41(1), 15-28

Fahrenberg J. Die Freiburger Beschwerdenliste (FBL) [in Germann]. Z Klin Psychol 1975;4:79-100.

Frei P, Mohler E, Bürgi A, Fröhlich J, Neubauer G, Braun-Fahrländer C. Röösli M; QUALIFEX-team. A prediction model for personal radio frequency electromagnetic field exposure. Sci Total Environ 2009;408:102-8.

Frei P, Mohler E, Bürgi A, Fröhlich J, Neubauer G, Braun-Fahrländer C, Röösli M, QUALIFEX- team. Classification of personal exposure to radio frequency electromagnetic fields (RF-EMF) for epidemiological research: evaluation of different exposure assessment methods. Environ Int 2010;36:714-20.

Frick U, Mayer M, Hauser S, Binder H, Rosner R, Eichhammer P. Entwicklung eines deutschsprachigen messinstrumentes für "Elektrosmog-Beschwerden" [in German]. Umweltmed Forsch Prax 2006;11:103_ 13.

Grimes DA, Schulz KF. Bias and causal associations in observational research. Lancet 2002;359:248-52.

Haugland S, Wold B. Subjective health complaints in adolescence - reliability and validity of survey methods. J Adolesc 2001;24:611-24.

Heinrich S, Kühnlein A, Thomas S, Praml G, von Kries R, Radon K. Association between exposure to radiofrequency electromagnetic field exposure and acute well-being in children and adolescents. Environ Health 2010;9:75.

Heinrich S, Thomas S, Praml G, von Kries R, Radon K. The impact of exposure to radio frequency electromagnetic fields on chronic well-being in young people - a cross sectional study based on personal dosimetry. Environ Int 2011;37:26-30.

Herr CE, Nieden A, Lindenstruth M, Stilianakis NI, Seitz H, Eikmann TF. Relating use of mobile phones to reported sleep quality. Somnologie 2005;9:199-202.

Higgins JPT, Thompson SG, Deeks JJ, Altman DG. Measuring inconsistency in metaanalyses. BMJ 2003;327:557-60.

Hiller W, Goebel G, Schindelmann U. Systematische fremdbeurteilung von patienten mit chronischem tinnitus (Strukturiertes Tinnitus-Interview) [in German]. Diagnostica 2000;46:93-102.

Hutter HP, Moshammer $\mathrm{H}$, Wallner $\mathrm{P}$, Kundi M. Public perception of risk concerning celltowers and mobile phones. Soz Praventivmed 2004;49:62-6.

Hutter HP, Moshammer H, Wallner P, Kundi M. Subjective symptoms, sleeping problems, and cognitive performance in subjects living near mobile phone base stations. J Occup Environ Med 2006;63:307-13.

Hutter HP, Moshammer H, Wallner P, Cartellieri M, Denk-Linnert DM, Katzinger M, Ehrenberger K, Kundi M. Tinnitus and mobile phone use. Occup Environ Med 2010;67:8048.

International Commission on Non-Ionizing Radiation Protection. Guidelines for limiting exposure to timevarying electric, magnetic, and electromagnetic fields (up to $300 \mathrm{GHz}$ ). Health Phys 1998;74:494-522.

Inyang I, Benke G, McKenzie R, Abramson M. Comparison of measuring instruments for radiofrequency radiation from mobile telephones in epidemiological studies: implications for exposure assessment. J Expo Sci Environ Epidemiol 2008;18:134-41.

Johansson A, Nordin S, Heiden M, Sandstrom M. Symptoms, personality traits, and stress in people with mobile phone-related symptoms and electromagnetic hypersensitivity. J Psychosom Res 2010;68:37-45.

Johns MW. A new method for measuring daytime sleepiness: the Epworth Sleepiness Scale. Sleep 1991;14:540-5.

Kecklund G, Åkerstedt T. The psychometric properties of the Karolinska Sleep Questionnaire. J Sleep Res 1992;1:113.

Khan MM. Adverse effects of excessive mobile phone use. Int J Occup Med Environ Health 2008;21:289_ 93.

King A, Wold B, Tudor-Smith C, Harel Y. The health of youth. A cross-national survey. WHO Reg Publ Eur Ser 1996;69:1-222.

Koivusilta L, Lintonen T, Rimpelä A. Orientations in adolescent use of information and communication technology: a digital divide by sociodemographic background, educational career, and health. Scand J Public Health 2007;35:95-103.

Kosinski M, Bayliss MS, Bjorner JB, Ware Jr JE, Garber WH, Batenhorst A, Cady R, Dahlöf CGH, Dowson A, Tepper S. A six-item short-form survey for measuring headache impact: the HIT-6. Qual Life Res 2003;12:963-74.

Kucer N. Some ocular symptoms experienced by users of mobile phones. Electromagn Biol Med 2008;27:205-9.

Landgrebe M, Frick U, Hauser S, Langguth B, Rosner R, Hajak G, Eichhammer P. Cognitive and neurobiological alterations in electromagnetic hypersensitive patients: results of a case-control study. Psychol Med 2008;38:1781-91.

Mann S. Assessing personal exposures to environmental radiofrequency electromagnetic fields. CR Phys 2010;11:541-55. 
Baliatsas, C., Kamp, I. van, Bolte, J., Schipper, M., Yzermans, J., Lebret, E. Non-specific physical sympton's and electromagnetic field exposure in the general population: can we get more specific? A systematic reviem Environment International: 2012, 41(1), 15-28

Meo SA, Al-Drees. Do mobile phones cause hearing and vision complaints? A preliminary report. Saudi Med J 2005a;26:882-3.

Meo SA, Al-Drees A. Mobile phone related-hazards and subjective hearing and vision symptoms in the Saudi population. Int J Occup Med Environ Health 2005b;18: 45-9.

Electromagnetic hypersensitivity. Mild KH, Repacholi M, van Deventer E, Ravazzani P, editors. Proceedings of the International Workshop on Electromagnetic Field Hypersensitivity Prague, Czech Republic: World Health Organization; 2006.

Milde-Busch A, von Kries R, Thomas S, Heinrich S, Straube A, Radon K. The association between use of electronic media and prevalence of headache in adolescents: results from a population-based crosssectional study. BMC Neurol 2010;10:12.

Mohler E, Frei P, Fahrländer CB, Fröhlich J, Neubauer G, Röösli M. Effects of everyday radiofrequency electromagnetic-field exposure on sleep quality: a cross-sectional study. Radiat Res 2010;174:347-56.

Mortazavi SMJ, Ahmadi J, Shariati M. Prevalence of subjective poor health symptoms associated with exposure to electromagnetic fields among university students.

Bioelectromagnetics 2007;28:326-30.

Navarro EA, Segura J, Portoles M, Gomez-Perretta C. The microwave syndrome: a preliminary study in Spain. Electromagn Biol Med 2003;22:161-9.

Neubauer G, Feychting M, Hamnerius Y, Kheifets L, Kuster N, Ruiz I, Schüz J, Uberbacher R, Wiart J, Röösli M. Feasibility of future epidemiological studies on possible health effects of mobile phone base stations. Bioelectromagnetics 2007;28:224-30.

Osterberg K, Persson R, Karlson B, Carlsson EF, Orbaek P. Personality, mental distress, and subjective health complaints among persons with environmental annoyance. Hum Exp Toxicol 2007;26:231-41.

Ott H, Oswald I, Fichte K, Sastre M. VIS-A und VIS-M (in German). Collegium Internationale Psychiatrie Scalarum (eds). Internationale Skalen für Psychiatrie 1981, Weinheim.

Pennarola E, Barletta R, Quarto E, Pennarola R. Operation aspects of risk in the electromagnetic fields exposition (in Italian). G Ital Med Lav Ergon 2007;23:785-7.

Persson R, Carlsson EF, Osterberg K, Orbaek P, Karlson B. A two-week monitoring of self-reported arousal, worry and attribution among persons with annoyance attributed to electrical equipment and smells. Scand J Psychol 2008;49:345-56.

Petrie KJ, Sivertsen B, Hysing M, Broadbent E, Moss-Morris R, Eriksen HR, Ursin H. Thoroughly modern worries. The relationship of worries about modernity to reported symptoms, health and medical care utilization. J Psychosom Res 2001;51:395-401.

Preece AW, Georgiou AG, Dunn EJ, Farrow SC. Health response of two communities to military antennae in Cyprus. J Occup Environ Med 2007;64:402-8.

Punamäki R, Wallenius M, Nygard C, Saarni L, Rimpelä A. Use of information and communication technology (ICT) and perceived health in adolescence: the role of sleeping habits and waking-time tiredness. J Adolesc 2007;30:569-85.

Röösli M. Radiofrequency electromagnetic field exposure and non-specific symptoms of ill health: a systematic review. Environ Res 2008;107:277-87.

Röösli M, Frei P, Mohler E, Hug K. Systematic review on the health effects of exposure to radiofrequency electromagnetic fields from mobile phone base stations. Bull World Health Organ 2010;88:887-96.

Röösli M, Hug K. Wireless communication fields and non-specific symptoms of ill health: a literature review. Wien Med Wochenschr 2011;9-10:240-50.

Rothman KJ. Health effects of mobile telephones. Epidemiology 2009;20:653-5.

Rubin GJ, Das MJ, Wessely S. A systematic review of treatments for electromagnetic hypersensitivity. Psychother Psychosom 2006;75:12-8.

Rubin GJ, Cleare AJ, Wessely S. Psychological factors associated with self-reported sensitivity to mobile phones. J Psychosom Res 2008;64:1-9.

Rubin GJ, Nieto-Hernandez R, Wessely S. Idiopathic environmental intolerance attributed to electromagnetic fields (formerly 'electromagnetic hypersensitivity'): an updated systematic review of provocation studies. Bioelectromagnetics 2009;31: 1-11.

Rücker G, Schwarzer G, Carpenter JR, Schumacher M. Undue reliance on $\mathrm{I}^{2}$ in assessing heterogeneity may mislead. BMC Med Res Methodol 2008;8:79.

Sandstrom M, Wilen J, Oftedal G, Mild-Hansson K. Mobile phone use and subjective symptoms. Comparison of symptoms experienced by users of analogue and digital mobile phones. Occup Med 2001;51:25-35.

Santini R, Seigne M, Bonhomme-Faivre L, Bouffet S, Defrasne E, Sage M. Symptoms experienced by users of digital cellular phones: a study of a French engineering school. Electromagn Biol Med 2002;21:81-8. 
Baliatsas, C., Kamp, I. van, Bolte, J., Schipper, M., Yzermans, J., Lebret, E. Non-specific physical symptomis and electromagnetic field exposure in the general population: can we get more specific? A systematic reviem Environment International: 2012, 41(1), 15-28

Santini R, Santini P, Danze JM, Le Ruz P, Seigne M. Enquete sur la sante de riverains de stations relais de telephonie mobile: Incidences de l'age des sujets, de la duree de leur exposition et de leur position par rapport aux antennas et autres sources electromagnetiques. . [in French]Pathol Biol 2003;51:412-5.

Schmitt BE, Gugger M, Augustiny K, Bassetti C, Radanov BP. Prevalence of sleep disorders in an employed Swiss population: results of a questionnaire survey. Schweiz Med Wochenschr 2000;130:7728.

Schreier N, Huss A, Röösli M. The prevalence of symptoms attributed to electromagnetic field exposure: a cross-sectional representative survey in Switzerland. Soz Praventivmed 2006;51:202-9.

Schrottner J, Leitgeb N. Sensitivity to electricity - temporal changes in Austria. BMC Public Health 2008;8:310.

Schüz J, Waldemar G, Olsen JH, Christoffer Johansen C. Risks for central nervous system diseases among mobile phone Subscribers: a Danish Retrospective Cohort Study. PloS ONE 2009;4:e4389.

Soderqvist F, Carlberg M, Hardell L. Use of wireless telephones and self-reported health symptoms: a population-based study among Swedish adolescents aged 15-19 years. Environ Health 2008;7:18.

Sutton Aj, Abrams KR, Jones DR, Sheldon TA, Song F. Methods for meta-analysis in medical research. Chichester: Wiley; 2000.

Szyjkowska A, Bortkiewicz A, Szymczak W, Makowiec-Dabrowska T. Subiektywne dolegliwosci u osob korzystajacych z telefonow komorkowych - badanie pilotazowe [in Polish]. Pol Merk Lek 2005;112:52932.

Thomas S, Kuhnlein A, Heinrich S, Praml G, Nowak D, von Kries R, Radon K. Personal exposure to mobile phone frequencies and well-being in adults: a cross-sectional study based on dosimetry.

Bioelectromagnetics 2008;29:463-70.

Thomée S, Eklöf M, Gustafsson E, Nilsson R, Hagberg M. Prevalence of perceived stress, symptoms of depression and sleep disturbances in relation to information and communication technology (ICT) use among young adults - an explorative prospective study. Comput Hum Behav 2007;23:1300-21.

Thomée S, Härenstam A, Hagberg M. Mobile phone use and stress, sleep disturbances, and symptoms of depression among young adults - a prospective cohort study. BMC Public Health 2011;11:66.

Vol Elm E, Altman DG, Egger M, Pocock SJ, Gøtzsche PC, Vandenbroucke JP. The strengthening the reporting of observational studies in epidemiology (STROBE) statement: guidelines for reporting observational studies. Lancet 2007;370:1453-7.

Von Zerssen D. Complaint list. Manual. Weinheim: Beltz; 1976.

Vrijheid M, Armstrong BK, Bédard D, Brown J, Deltour I, lavarone I, Krewski D, Lagorio S, Moore S, Richardson L, Giles GG, McBride M, Parent ME, Siemiatycki J, Cardis E. Recall bias in the assessment of exposure to mobile phones. J Expo Sci Environ Epidemiol 2009;19:369-81.

Yzermans CJ, Oskam SB. Clustering, continuiteit en comorbiditeit in de huisartsenpraktijk [In Dutch]. Doctoral Dissertation.University of Amsterdam, 1990.

Ware JE, Snow KK, Kosinski M, Gandek B. SF-36 health survey manual and interpretation guide. Boston, MA: New England Medical Center, The Health Institute; 1993.

World Health Organization. Electromagnetic fields and public health, WHO Fact Sheet No. 296. 2005. Available at http://www.emfandhealth.com/WHO_EMSensitivity.pdf.

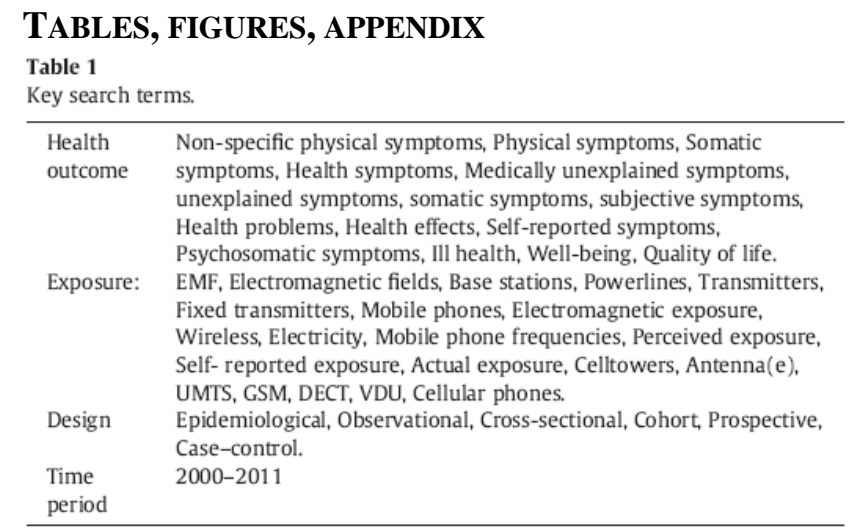


Table 2

Observational studies on actual $24 \mathrm{~h} \mathrm{EMF}$ exposure and NSPS.

\begin{tabular}{|c|c|c|c|c|c|c|c|c|}
\hline Reference & $\begin{array}{l}\text { Study } \\
\text { design }\end{array}$ & $\begin{array}{l}\text { Actual Sample characteristics } \\
\text { (response rate) }\end{array}$ & $\begin{array}{l}\text { Exposure source and average } \\
\text { field strength range }\end{array}$ & $\begin{array}{l}\text { Exposure } \\
\text { assessment }\end{array}$ & Outcome assessment & $\begin{array}{l}\text { Variables included } \\
\text { as possible confounders }\end{array}$ & $\begin{array}{l}\text { NSPS significantly associated with the } \\
\text { highest actual exposure levels }\end{array}$ & 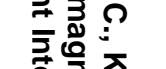 \\
\hline $\begin{array}{l}\text { a Abelin et al., } \\
2005 \text { (1992) }\end{array}$ & $\begin{array}{l}\text { Cross- } \\
\text { sectional }\end{array}$ & $\begin{array}{l}404(60 \%) \text { subjects with mean } \\
\text { age }=45 \mathrm{y} .0 \text {. living in the } \\
\text { vicinity of a broadcast } \\
\text { transmitter in Switzerland. } \\
\text { F. }=57.6 \% \text {. }\end{array}$ & $\begin{array}{l}\text { Short-wave broadcast } \\
\text { transmitter, } \leq 0.38 \mathrm{~V} / \mathrm{m} \\
\text { (reference category) to }<3.8 \mathrm{~V} / \mathrm{m} \text {. }\end{array}$ & $\begin{array}{l}\text { Field strength } \\
\text { measurements in } \\
\text { different outdoor } \\
\text { locations based on } \\
\text { actual distance from } \\
\text { the exposure source. }\end{array}$ & $\begin{array}{l}\text { Self-constructed symptom } \\
\text { questionnaire on sleep } \\
\text { problems. }\end{array}$ & $\begin{array}{l}\text { Age, gender, education, } \\
\text { attribution, duration of } \\
\text { time lived at the same } \\
\text { location. }\end{array}$ & $\begin{array}{l}\text { Nervousness }(\mathrm{OR}=2.77 ; 95 \% \mathrm{Cl}=1.62- \\
4.74) \text {, difficulties in falling asleep } \\
(\mathrm{OR}=3.35 ; 95 \% \mathrm{C}=1.86-6.03) \text {, difficulties } \\
\text { in maintaining sleep }(\mathrm{OR}=3.19 ; 95 \% \\
\mathrm{C}=1.84-5.52) \text {, joint pain }(\mathrm{OR}=2.46 ; 95 \% \\
\mathrm{C}=1.37-4.43) \text {, limb pain: }(\mathrm{OR}=2.51 ; 95 \% \\
\mathrm{C}=1.15-5.50 \text {, cough and sputum } \\
(\mathrm{OR}=2.80 ; 95 \% \mathrm{C}=1.18-6.64) \text {. }\end{array}$ & 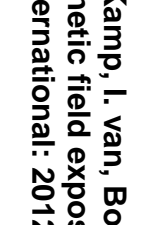 \\
\hline $\begin{array}{l}\text { Abelin et al., } \\
2005 \text { (1996) }\end{array}$ & $\begin{array}{l}\text { Cross- } \\
\text { sectional }\end{array}$ & $\begin{array}{l}399(77 \%) \text { subjects with mean } \\
\text { age }=49 \text { y.o. living in the } \\
\text { vicinity of a short-wave broad- } \\
\text { cast transmitter in Switzerland. } \\
\text { F. } g=57 \% \text {. }\end{array}$ & $\begin{array}{l}\text { Short-wave broadcast } \\
\text { transmitter, } \leq 0.38 \mathrm{~V} / \mathrm{m} \\
\text { (reference category) to }<3.8 \mathrm{~V} / \mathrm{m} \text {. }\end{array}$ & $\begin{array}{l}\text { Field strength } \\
\text { measurements in } \\
\text { different outdoor } \\
\text { locations based on } \\
\text { actual distance from } \\
\text { the exposure source. }\end{array}$ & $\begin{array}{l}\text { Self-constructed symptom } \\
\text { questionnaire on sleep } \\
\text { problems. }\end{array}$ & $\begin{array}{l}\text { Age, gender, education, } \\
\text { attribution, duration of } \\
\text { time lived at the same } \\
\text { location. }\end{array}$ & $\begin{array}{l}\text { Difficulties in falling asleep }(p=0.006) \text {, } \\
\text { difficulties in maintaining sleep }(p=0.001) \text {, } \\
\text { nervousness/restlessness ( } p=0.024) \text {. }\end{array}$ & 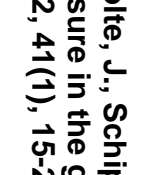 \\
\hline $\begin{array}{l}\text { Abdel-Rassoul } \\
\text { et al., } 2006\end{array}$ & $\begin{array}{l}\text { Cross- } \\
\text { sectional }\end{array}$ & $\begin{array}{l}165 \text { subjects ( } 80 \text { controls) with } \\
\text { mean age }=39 \text { y.o. living or } / \\
\text { and working in a building in } \\
\text { the vicinity of a mobile phone } \\
\text { base station in Egypt. } \\
\text { F.g }=42.4 \% \text {. }\end{array}$ & $\begin{array}{l}\text { Mobile phone base station, } \\
<0.61 \mathrm{~V} / \mathrm{m} \text { (reference category) } \\
\text { to } 0.614-<5.0 \mathrm{~V} / \mathrm{m} \text { (highest } \\
\text { exposure). }\end{array}$ & $\begin{array}{l}\text { Spot field strength } \\
\text { measurements in } \\
\text { locations within and } \\
\text { outside the } \\
\text { "exposed" building. }\end{array}$ & $\begin{array}{l}\text { Self-constructed symptom } \\
\text { questionnaire on various } \\
\text { NSPS. }\end{array}$ & $\begin{array}{l}\text { Age, gender, education, } \\
\text { smoking habits, mobile } \\
\text { phone use. }\end{array}$ & $\begin{array}{l}\text { Headache }(\mathrm{OR}=2.77 ; 95 \% \mathrm{Cl}=1.06-7.4) \text {, } \\
\text { memory changes }(\mathrm{OR}=7.48 ; 95 \% \mathrm{Cl}=2.29- \\
26.98) \text {, dizziness }(\mathrm{OR}=4.41 ; 95 \% \mathrm{Cl}=1.29- \\
16.46) \text {, sleep disturbances }(\mathrm{OR}=2.77 ; 95 \% \\
\mathrm{Cl}=1.06-7.4) \text {, tremors }(\mathrm{p}<0.01) \text {. }\end{array}$ & 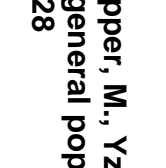 \\
\hline $\begin{array}{l}\text { Altpeter et al., } \\
2006 \text { (baseline } \\
\text { phase) }\end{array}$ & Longitudinal & $\begin{array}{l}54 \text { subjects } 24-70 \text { y.o. living in } \\
\text { the vicinity of a short-wave } \\
\text { broadcast transmitter in Swit- } \\
\text { zerland. F.g }=61 \% \text {. }\end{array}$ & $\begin{array}{l}\text { Short-wave broadcast } \\
\text { transmitter, } 0.15 \mathrm{~V} / \mathrm{m} \text { (reference } \\
\text { category) to } 0.98 \mathrm{~V} / \mathrm{m} \text { (highest } \\
\text { exposure). }\end{array}$ & $\begin{array}{l}\text { Spot field strength } \\
\text { measurements and } \\
\text { calculations. }\end{array}$ & $\begin{array}{l}\text { Sleep } \log \text { (VIS-M, } \\
\text { Collegium Internationale } \\
\text { Psychiatriae Scalarum, } \\
\text { 4th edition) (Ott et al., } \\
\text { 1981). }\end{array}$ & Age, gender. & $\begin{array}{l}\text { Sleep quality (morning tiredness versus } \\
\text { freshness) (regression coefficient }=3.85 \text {; } \\
95 \% \mathrm{Cl}=1.72-5.99 \text { ). }\end{array}$ & 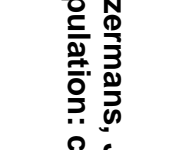 \\
\hline $\begin{array}{l}\text { Hutter et al., } \\
2006\end{array}$ & $\begin{array}{l}\text { Cross- } \\
\text { sectional }\end{array}$ & $\begin{array}{l}336 \text { (64\%) subjects } 18-91 \text { y.o. } \\
\text { randomly selected from } \\
\text { telephone register entries, } \\
\text { living in urban and rural areas } \\
\text { near mobile phone base } \\
\text { stations in Austria. F.g }=59 \% .\end{array}$ & $\begin{array}{l}\text { Mobile phone base stations } \\
\text { (GSM), } 0.08 \mathrm{~V} / \mathrm{m} \text { (reference } \\
\text { category) to } 2.5 \mathrm{~V} / \mathrm{m} \text { (highest } \\
\text { exposure). }\end{array}$ & $\begin{array}{l}\text { Spot field strength } \\
\text { measurements in } \\
\text { bedrooms. }\end{array}$ & $\begin{array}{l}\text { Items from Von Zerssen } \\
\text { complaint list (Von Zerssen, } \\
\text { 1976) and PSQI (Pittsburgh } \\
\text { Sleep Quality Index) (Buysse } \\
\text { et al., 1989). }\end{array}$ & $\begin{array}{l}\text { Age, gender, mobile } \\
\text { phone use, worry about } \\
\text { health effects from mobile } \\
\text { phone base stations. }\end{array}$ & $\begin{array}{l}\text { Headache }(\mathrm{OR}=3.06 ; 95 \% \mathrm{Cl}=1.22-7.67) \text {, } \\
\text { cold hands or feet }(\mathrm{OR}=2.57 ; 95 \% \\
\mathrm{C}=1.16-5.67) \text {, concentration difficulties } \\
(\mathrm{OR}=2.55 ; 95 \% \mathrm{C}=1.07-6.08)\end{array}$ & \begin{tabular}{ll}
$\sum_{0}$ & \multicolumn{1}{c}{} \\
0 & 0 \\
0 & 0 \\
0 & 0
\end{tabular} \\
\hline $\begin{array}{l}\text { Preece et al., } \\
2007\end{array}$ & $\begin{array}{l}\text { Cross- } \\
\text { sectional }\end{array}$ & $\begin{array}{l}1870(87 \%) \text { subjects } \leq 18 \text { y.o. } \\
\text { living in three villages } \\
\text { differently exposed to a } \\
\text { military antenna in Cyprus. } \\
\text { F.g }=66.2 \% \text {. }\end{array}$ & $\begin{array}{l}\text { Military antenna systems, } \\
<0.01 \mathrm{~V} / \mathrm{m} \text { (reference category) } \\
\text { to }>0.57 \mathrm{~V} / \mathrm{m} \text { (highest exposure). }\end{array}$ & $\begin{array}{l}\text { Field strength } \\
\text { measurements in } \\
\text { different locations in } \\
\text { the regions close to } \\
\text { the antenna. }\end{array}$ & $\begin{array}{l}\text { Self-constructed symptom } \\
\text { questionnaire on various NSPS } \\
\text { and SF-36 (Ware et al., 1993). }\end{array}$ & $\begin{array}{l}\text { Age, gender, education, } \\
\text { smoking habits, mobile } \\
\text { phone use, perceived } \\
\text { risk of health. }\end{array}$ & $\begin{array}{l}\text { Migraine }(\mathrm{OR}=3.32 ; 95 \% \mathrm{Cl}=2.14-5.15) \\
\text { headache }(\mathrm{OR}=4.16 ; 95 \% \mathrm{Cl}=2.96-5.84) \\
\text { dizziness }(\mathrm{OR}=5.64 ; 95 \% \mathrm{Cl}=3.69-8.62) \\
\text { HRQoL scores }(\mathrm{p}<0.05)\end{array}$ & 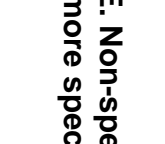 \\
\hline $\begin{array}{l}\text { Thomas et al., } \\
2008\end{array}$ & $\begin{array}{l}\text { Cross- } \\
\text { sectional }\end{array}$ & $\begin{array}{l}329(40 \%) \text { randomly selected } \\
\text { subjects } 18-65 \text { y.o. from }\end{array}$ & $\begin{array}{l}\text { Mobile phone base stations } \\
\text { (GSM, UMTS), DECT, WLAN, } \\
0.05-0.075 \mathrm{~V} / \mathrm{m} \text { (reference }\end{array}$ & $\begin{array}{l}\text { Field strength } \\
\text { measurements } \\
\text { based on personal }\end{array}$ & $\begin{array}{l}\text { For acute symptoms: Items } \\
\text { from Von Zerssen complaint } \\
\text { list (Von Zerssen, 1976). For }\end{array}$ & Age, gender. & N.S & 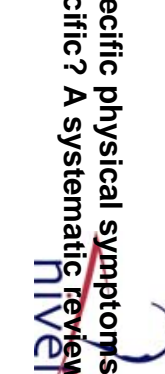 \\
\hline
\end{tabular}


registration offices of four cities category) to $0.05-0.3$ (highest

exposure).

\section{Berg-Beckhoff Cross- \\ et al., 2009 sectional}

1326 (85\%) subjects 15-71 y.o. Mobile phone base stations randomly selected from a $\quad$ (GSM, UMTS), FM radio, analog

nationwide panel sample mainly from urban regions

y. $P . g=50.8 \%$

TV and DVB-T, TETRA, DECT,

WLAN and Bluetooth, $<0.1 \mathrm{~V} / \mathrm{m}$

(reference category) to $0.1-$

Blettner et al., $\quad$ Cross- $\quad 26039$ subjects (58.6\%) $\quad$ Mobile phone base stations.

$14-69$ y.o. randomly selected

nationwide via emall

publishers and snow-ball sys-

tems in $\mathrm{Germany.} F=52 \%$

Schüz et al., Registry- Data for 420095 subjects

$2009 \quad$ based $\quad \geq 18$ y.o. in Denmark over a

b. c Heinrich et Cross-

al., 2010 sectional

randomly selected from

registration offices of four

in the south of Germany.

$\mathrm{F} . \mathrm{g}=51.5 \%$

Mobile phones.

Mobile phone base stations

GSM, UMTS), DECT, WLAN,

$\leq 0.05 \mathrm{~V} / \mathrm{m}$ (reference categ
to $0.12-0.62 \mathrm{~V} / \mathrm{m}$ (highest

exposure).

$\begin{array}{cl}\text { Mohler et al., } & \begin{array}{l}\text { Cross- } \\ 2010\end{array} \\ \text { sectional }\end{array}$

1212 (37\%) subjects 30-60 y.o. Mobile phone base stations

randomly selected from (GSM, UMTS), FM radio, analo

.

ence categ ory) to $0.01-0.49 \mathrm{~V} / \mathrm{m}$

(highest exposure)

1508 (52\%) subjects $13-17 \mathrm{y}$. randomly selected from

Mobile phone base stations sectional (GSM, UMTS), DECT, WLAN dosimeters during waking hours.

Spot field strength bedrooms.

Objectively

measured distan

to base stations

coding

Years of mobile

phone use based on

phone use based on
subscription records.

Field strength

measurements

dosimeters during

waking hours.

Geospatial modeling and exposure

based on exposure-

elated characteris-

tics and behaviors

Field strength

measurements

based on persona

dosimeters during

waking hours. chronic symptoms: Freiburg symptom list (Fahrenberg

complaint st (Von Zerssen, 1976), QII (Buysse et al., 1989)

HIT-6 (Headache Impact

and SF-36 (Ware et al, 1993). Frick symptom list (Frick et rack 2006$)$

Age, gender, education, mobile phone use,

N.S stress.

ge, gender, education, family income, region, urbanization level,

Hospital contacts for migraine Age, gender, time period. and vertigo.

ems from Von Zerssen mplaint list (Von

ge, gender, education, urbanization level,

mobile phone use, DEC base station.

Questions on general subjective sleep quality fiom

Age,

Age, gender, education,

perception, physical

Schity

2000) and Epworth Sleepiness alcohol consumption

self-reported disturbance

level, belief in health effects

due to RF-EMF exposure.

Items from the HBSC Survey

(Haugland and Wold,

Age, gender, education,

urbanization level,

enironmental worries,

mobile phone use, DECT

phone use, perceived

distance to mobile phon
$508(52 \%)$ subjects $13-17$.

Heinrich et al., Crossregistration offices of four $\mathrm{C}$ $\leq 0.05 \mathrm{~V} / \mathrm{m}$ (reference F.g $=51.5 \%$. to $0.12-0.62 \mathrm{~V} / \mathrm{m}$ (highest exposure

due to noise, urbanization

Actual distance to mobile phone base stations $(\leq 500 \mathrm{~m})$ with NSPS total scor $\mathrm{Cl}=0.32-0.37$ ).

For the total time period: Migraine ( $\mathrm{SHR}=1.2 ; 95 \% \mathrm{Cl}=1.1-1.3)$, vert SHR $=1.1 ; 95 \% \mathrm{Cl}=1.1-1.2)$.

Headache with exposure during morning 列 列

b Results from participants under the age of 12 years were excluded.

The studies of Heinrich et al. (2010, 2011) were based on the same sample. Abbreviations: C, Confidence interval; OR, Odds ratio; SHR, Standardized hospitalization ratio; N.S, no statistical significance; y.o., Years old; F.g, Female gender distribution; NSPS, Non-specific physical symptoms; GSM, Global system for mobile communications; NMT, Nordic mobile telephone; DECT, Digital enhanced cordless telecommunications; UMTS, Universal mobile telecommunications sys-

tem; WLAN, Wireless local area network; DVB-T, Digital video broadcasting-Terrestrial; TETRA, Terrestrial trunked radio; HRQoL, Health-related quality of life; BMI, Body mass index.

Fifance; y.o, Years old; F.g. Female gender distribution: NSPS, Non-specific physical symptoms; GSM, Global system for mobile communications; NMT, Nordic mobile telephone; DECT, Digital enhanced cordless telecommunications; VDT, Video display terminal; 3G, Third generation digital
phone; BMI, Body mass index. 
Table 3

Observational studies on perceived EMF exposure and NSPS.

\begin{tabular}{|c|c|c|c|c|c|c|c|}
\hline Reference & Study design & $\begin{array}{l}\text { Actual sample characteristics } \\
\text { (response rate) }\end{array}$ & Exposure source & $\begin{array}{l}\text { Self-reported exposure } \\
\text { assessment }\end{array}$ & Outcome assessment & $\begin{array}{l}\text { Variables included as possible } \\
\text { confounders }\end{array}$ & $\begin{array}{l}\text { NSPS significantly associated with } \\
\text { the highest perceived exposure } \\
\text { levels }\end{array}$ \\
\hline Chia et al., 2000 & $\begin{array}{l}\text { Cross- } \\
\text { sectional }\end{array}$ & $\begin{array}{l}808(45 \%) \text { randomly selected } \\
\text { subjects } 12-70 \text { y.o. living in an } \\
\text { urban area in Singapore. } \\
\text { F.g }=52.7 \% \text {. }\end{array}$ & Mobile phones (GSM, NMT). & $\begin{array}{l}\text { Daily calling duration } \\
\text { in minutes, daily } \\
\text { number of calls. }\end{array}$ & $\begin{array}{l}\text { Self-constructed symptom } \\
\text { questionnaire on symptoms } \\
\text { related to the central nervous } \\
\text { system. }\end{array}$ & $\begin{array}{l}\text { Age, gender, ethnicity, } \\
\text { occupational status, VDT use. }\end{array}$ & $\begin{array}{l}\text { For calling duration: Headache } \\
(\mathrm{p}=0.038) \text {. Users versus non-users: } \\
\text { Headache }(\mathrm{PR}=1.31 ; 95 \% \mathrm{Cl}=1.0- \\
1.70) \text {. }\end{array}$ \\
\hline $\begin{array}{l}\text { a Sandstrom } \\
\text { et al., } 2001 \\
\text { (Norway) }\end{array}$ & $\begin{array}{l}\text { Cross- } \\
\text { sectional }\end{array}$ & $\begin{array}{l}1872(58 \%) \text { randomly selected } \\
\text { registered mobile phone users } \\
\geq 18 \text { y.o. in Norway. F.g }=10 \% \text {. }\end{array}$ & Mobile phones (GSM, NMT). & $\begin{array}{l}\text { Daily calling duration } \\
\text { in minutes, daily } \\
\text { number of calls. }\end{array}$ & $\begin{array}{l}\text { Self-constructed symptom } \\
\text { questionnaire on various } \\
\text { NSPS. }\end{array}$ & $\begin{array}{l}\text { Age, gender, occupational status, } \\
\text { workplace location, work-related } \\
\text { psychosocial factors, VDT use. }\end{array}$ & 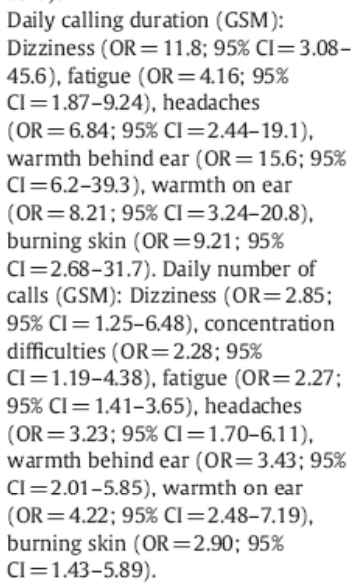 \\
\hline $\begin{array}{l}\text { a Sandstrom } \\
\text { et al., } 2001 \\
\text { (Sweden) }\end{array}$ & $\begin{array}{l}\text { Cross- } \\
\text { sectional }\end{array}$ & $\begin{array}{l}4520(66 \%) \text { randomly selected } \\
\text { registered mobile phone users } \\
\geq 18 \text { y.o. in Sweden. F. }=14 \%\end{array}$ & Mobile phones (GSM, NMT). & $\begin{array}{l}\text { Daily calling duration } \\
\text { in minutes, daily } \\
\text { number of calls. }\end{array}$ & $\begin{array}{l}\text { Self-constructed symptom } \\
\text { questionnaire on various } \\
\text { NSPS. }\end{array}$ & & $\begin{array}{l}\text { Daily calling duration (GSM): } \\
\text { Headaches (OR }=2.63 ; 95 \% \\
\mathrm{Cl}=1.22-5.67) \text {, warmth behind ear } \\
(\mathrm{OR}=26.9 ; 95 \% \mathrm{Cl}=10.0-72.2) \text {, } \\
\text { warmth on ear }(\mathrm{OR}=26.4 ; 95 \% \\
\mathrm{Cl}=10.3-66.9) \text {. Daily number of } \\
\text { calls }(\mathrm{GSM}) \text { : Dizziness }(\mathrm{OR}=2.85 ; \\
95 \% \mathrm{Cl}=1.25-6.48) \text {; concentration } \\
\text { difficulties }(\mathrm{OR}=2.28 ; 95 \% \\
\mathrm{Cl}=1.19-4.38) \text {, fatigue }(\mathrm{OR}=2.27 \text {; } \\
95 \% \mathrm{Cl}=1.41-3.65) \text {, headaches } \\
(\mathrm{OR}=3.23 ; 95 \% \mathrm{Cl}=1.70-6.11) \text {, } \\
\text { warmth behind ear }(\mathrm{OR}=3.34 ; 95 \% \\
\mathrm{Cl}=2.01-5.85) \text {, warmth on ear } \\
(\mathrm{OR}=4.22 ; 95 \% \mathrm{Cl}=2.48-7.19) \text {, } \\
\text { burning skin }(\mathrm{OR}=2.90 ; 95 \% \\
\mathrm{Cl}=1.43-5.89) \text {. }\end{array}$ \\
\hline Herr et al., 2005 & $\begin{array}{l}\text { Cross- } \\
\text { sectional }\end{array}$ & $\begin{array}{l}132 \text { subjects } \geq 18 \text { y.o. } \\
\text { voluntarily selected in } \\
\text { Germany. F.g }=54 \% \text {. }\end{array}$ & Mobile phones (GSM). & $\begin{array}{l}\text { Daily calling duration } \\
\text { in minutes. }\end{array}$ & PSOl (Buysse et al., 1989) & $\begin{array}{l}\text { Age, gender, daily working time, } \\
\text { stress, score on psychosomatic } \\
\text { symptoms. }\end{array}$ & N.S \\
\hline $\begin{array}{l}\text { Mortazavi et al., } \\
2007\end{array}$ & $\begin{array}{l}\text { Cross- } \\
\text { sectional }\end{array}$ & $\begin{array}{l}518(75 \%) \text { voluntarily selected } \\
\text { university students } \geq 18 \text { y.o. in } \\
\text { Iran. F.g }=66.2 \% \text {. }\end{array}$ & $\begin{array}{l}\text { Computer monitors, mobile } \\
\text { phones, cordless phones. }\end{array}$ & $\begin{array}{l}\text { Possession of a device } \\
\text { and/or daily use at least } \\
\text { for } 30 \text { seconds the last } \\
3 \text { months (for mobile }\end{array}$ & $\begin{array}{l}\text { Self-constructed symptom } \\
\text { questionnaire on various } \\
\text { NSPS. }\end{array}$ & $\begin{array}{l}\text { Age, gender, occupational status, } \\
\text { VDT use, medical history. }\end{array}$ & $\begin{array}{l}\text { For cordless phones: Concentration } \\
\text { difficulties }(\mathrm{p}<0.05) \text {, attention } \\
\text { difficulties }(\mathrm{p}<0.05) \text {. }\end{array}$ \\
\hline
\end{tabular}




\section{9 (63.5\%) randomly \\ or computer monitors} selected young subject 15-19 y.o. in Sweden. $\mathrm{g}=52.2$

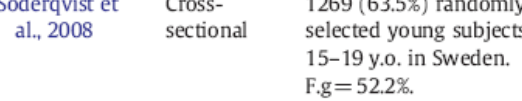

G), wireless phones (DECT).

in minutes.

questor.

Mobile phones, VDT/computer

1025 (51.5\%) subjects

et al., 2010 sectiona

3-17 y.0. randomly selec

for cities in Germany: 489

meeting criteria for increase

headache report and 536

reporting no
$\mathrm{F} g=512 \%$

'Heinrich et al., Cross-

1508 (52\%) subjects 13-17 y.o. Mobile phones.

registration offices of fou

cities in the south of Germany. F.g $=51.5 \%$.

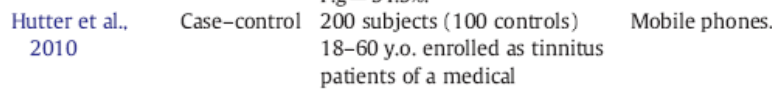

epartment in Vicha Austria.

Mohler et al

1212 (37\%) subjects 30-60 y.o. Mobile phones, mobile phone population registries in the Basel in Switzerland. F.g = 58\%

\section{Heinrich et al., Cross-}

1508 (52\%) subjects 13-17 y.o. Mobile phones, DECT phones. andomly selected from

cities in the south of Germany.

$\mathrm{F} . \mathrm{g}=51.5 \%$.

d Thomée et al., Prospective $4156(36 \%)$ subjects 20-24 y.o. Mobile phones.

randomly selected from population registries in

Daily use in minutes. King et al., 1996) and selfdifferent types of headache based on the International Classification of Headach

Daily calling duration in minutes.

from Von Zersse complaint list (Von Zersse 1976) on various (acute)

Age, gender, education,

Past and/or present mobile phone use in terms of possession. daily average call duration, cumulative hours of use and

years of use.

duration, perception of being
generally exposed.

Clinical examination, selfreported questionnaire on

tinnitus (Structured Tinnit

Interview) (Hiller et al., measurements.

Age, gender, socio-economic sta-

tus, family condition.

Questions on general

Questions on general
subjective sleep quality

the Swiss Health Survey questionnaire (Schm 2000) and Epworth 1991).

Daily use.

Items from the HBSC Survey (Haugland and Wold, 2001)

ge, gender, education,

Frequency of daily calls Items from the Karolinska $\begin{array}{ll}\text { Frequency of dailly calls } & \text { Items from the Rare } \\ \text { and SMS-type } & \text { Sleep Questionnaire }\end{array}$ messages. (Kecklund and Ákerstedt,

Age, gender, education, marital status, BMI, stress perception, physical activity smoking habt reported disturbance due to noise, effects due to RF-EMF exposure. Age, gender, education, mobile phone base

Gender, education, occupational status, relationship status (the

a Analyses yielded similar associations for NMT use

b The studes of Milde-Busch et al (2010). Heinrich et al $(2010,2011)$ were based on the same sample.

$c$ Results from participants under the age of 12 years were excluded.

Age, gender,
ment use.
For mobile phones (total use): Asthinatic symptoms (OR=1.8; 95\% $\mathrm{Cl}=1.1-3.0)$, headache $(\mathrm{OR}=1.5$ $95 \% \mathrm{Cl}=1.1-2.0)$, concentration difficulties $(\mathrm{OR}=1.4 ; 95 \% \mathrm{~d}=1.1$ 1.9). For DECT (total ase): Asthmatic 22), headache ( $O R=1.5 \cdot 95 \%$ $\mathrm{Cl}=1.2-2.1)$, concentration difficulties $(\mathrm{OR}=1.4 ; 95 \% \mathrm{Cl}=1.03$ $1.9)$, tiredness $(O R=1.3 ; 95 \%$ N.S $1.01-1.8)$.

For mobile phone use: Headache $\mathrm{OR}=1.55 ; 95 \% \mathrm{Cl}=1.05-2.29)$, irritation $(\mathrm{OR}=1.64 ; 95 \% \mathrm{Cl}=1.10$ $2.44)$, fatigue $(0$.
$\mathrm{Cl}=1.22-2.56)$.

For long-term mobile phone use in years $(4 \leq)$ on the side of the hea that tinnitus occurred: Tinnitus
$(\mathrm{OR}=1.95 ; 95 \% \mathrm{Cl}=1.00-3.80)$

N.S

For mobile phone use: Irritation $(\mathrm{OR}=1.48 ; 95 \% \mathrm{Cl}=1.13-1.93)$. For (OR phone use. Irritation

At baseline: Sleep problems $(\mathrm{PR}=1.4 ; 95 \% \mathrm{Cl}=130-1.62)$ follow-up: Sleep problems
$(\mathrm{PR}=1.3 ; 95 \% \mathrm{Cl}=1.06-1.66)$ 
Table 4

Risk for three basic categories of bias ${ }^{*}$ in observational studies on objectively measured EMF strength and NSPS.

\begin{tabular}{|c|c|c|c|}
\hline Reference & Exposure measurement bias & Selection bias & Confounding \\
\hline Abelin et al., 2005 (1992) & $\begin{array}{l}++ \text { (Although exposure assessment was relatively } \\
\text { adequate for that specific frequency no indoor } \\
\text { measurements were performed) }\end{array}$ & $\begin{array}{l}+++ \text { (Possibility for awareness bias, increased } \\
\text { possibility for non-response bias) }\end{array}$ & $\begin{array}{l}++(A \text { few variables } \\
\text { were considered })\end{array}$ \\
\hline Abelin et al., 2005 (1996) & $\begin{array}{l}++ \text { (Although exposure assessment was relatively } \\
\text { adequate for that specific frequency no indoor } \\
\text { measurements were performed) }\end{array}$ & $\begin{array}{l}+++ \text { (Increased possibility for awareness bias } \\
\text { and nonresponse bias) }\end{array}$ & $\begin{array}{l}++(A \text { few variables } \\
\text { were considered })\end{array}$ \\
\hline Abdel-Rassoul et al., 2006 & $\begin{array}{l}+++(\text { Crude exposure assessment, no recent } \\
\text { measurements were available) }\end{array}$ & $\begin{array}{l}+++ \text { (Increased possibility for awareness bias } \\
\text { and nonresponse bias) }\end{array}$ & $\begin{array}{l}++(A \text { few variables } \\
\text { were considered })\end{array}$ \\
\hline Altpeter et al., 2006 (baseline) & $\begin{array}{l}++ \text { (Although exposure assessment was relatively } \\
\text { adequate for that specific frequency no indoor } \\
\text { measurements were performed) }\end{array}$ & +++ (Increased possibility for awareness bias) & $\begin{array}{l}++(\mathrm{A} \text { few variables } \\
\text { were considered })\end{array}$ \\
\hline Hutter et al., 2006 & $++($ Small exposure contrast $)$ & $\begin{array}{l}++ \text { (Subjects that agreed to participate might } \\
\text { constitute a selective population group with } \\
\text { increased EMF-related concerns) }\end{array}$ & + \\
\hline Preece et al., 2007 & $\begin{array}{l}+++ \text { (No indoor measurements were performed, } \\
\text { conservative calculation methods) }\end{array}$ & $\begin{array}{l}+++ \text { (Increased possibility for awareness bias, } \\
\text { increased prevalence of EMF-related concerns in } \\
\text { the "exposed" groups) }\end{array}$ & + \\
\hline Thomas et al., 2008 & $++($ Small exposure contrast $)$ & $\begin{array}{l}++ \text { (Subjects that agreed to participate might } \\
\text { constitute a selective population group with } \\
\text { increased EMF-related concerns) }\end{array}$ & $\begin{array}{l}++(\mathrm{A} \text { few variables } \\
\text { were considered })\end{array}$ \\
\hline Berg-Beckhoff et al., 2009 & $++($ small exposure contrast $)$ & $\begin{array}{l}++ \text { (increased prevalence of EMF-related concerns } \\
\text { among subjects participating in measurements) }\end{array}$ & + \\
\hline Blettner et al., 2009 & +++ (Use of poor exposure proxies) & $\begin{array}{l}++ \text { (Subjects that agreed to participate might } \\
\text { constitute a selective population group with } \\
\text { increased EMF-related concerns) }\end{array}$ & + \\
\hline Heinrich et al., 2010 & $++($ Small exposure contrast $)$ & $\begin{array}{l}++ \text { (Subjects that agreed to participate might } \\
\text { constitute a selective population group with } \\
\text { increased EMF-related concerns) }\end{array}$ & + \\
\hline Mohler et al., 2010 & $++($ Small exposure contrast $)$ & ++ (Possibility for nonresponse bias) & + \\
\hline Heinrich et al., 2011 & $++($ Small exposure contrast $)$ & $\begin{array}{l}++ \text { (Subjects that agreed to participate might } \\
\text { constitute a selective population group with } \\
\text { increased EMF-related concerns) }\end{array}$ & + \\
\hline
\end{tabular}

"Note: + low risk for bias, ++ medium risk for bias, +++ high risk for bias. 
Baliatsas, C., Kamp, I. van, Bolte, J., Schipper, M., Yzermans, J., Lebret, E. Non-specific physical sympton's and electromagnetic field exposure in the general population: can we get more specific? A systematic review Environment International: 2012, 41(1), 15-28

Fig. 1. Flow diagram outlining the study selection process.

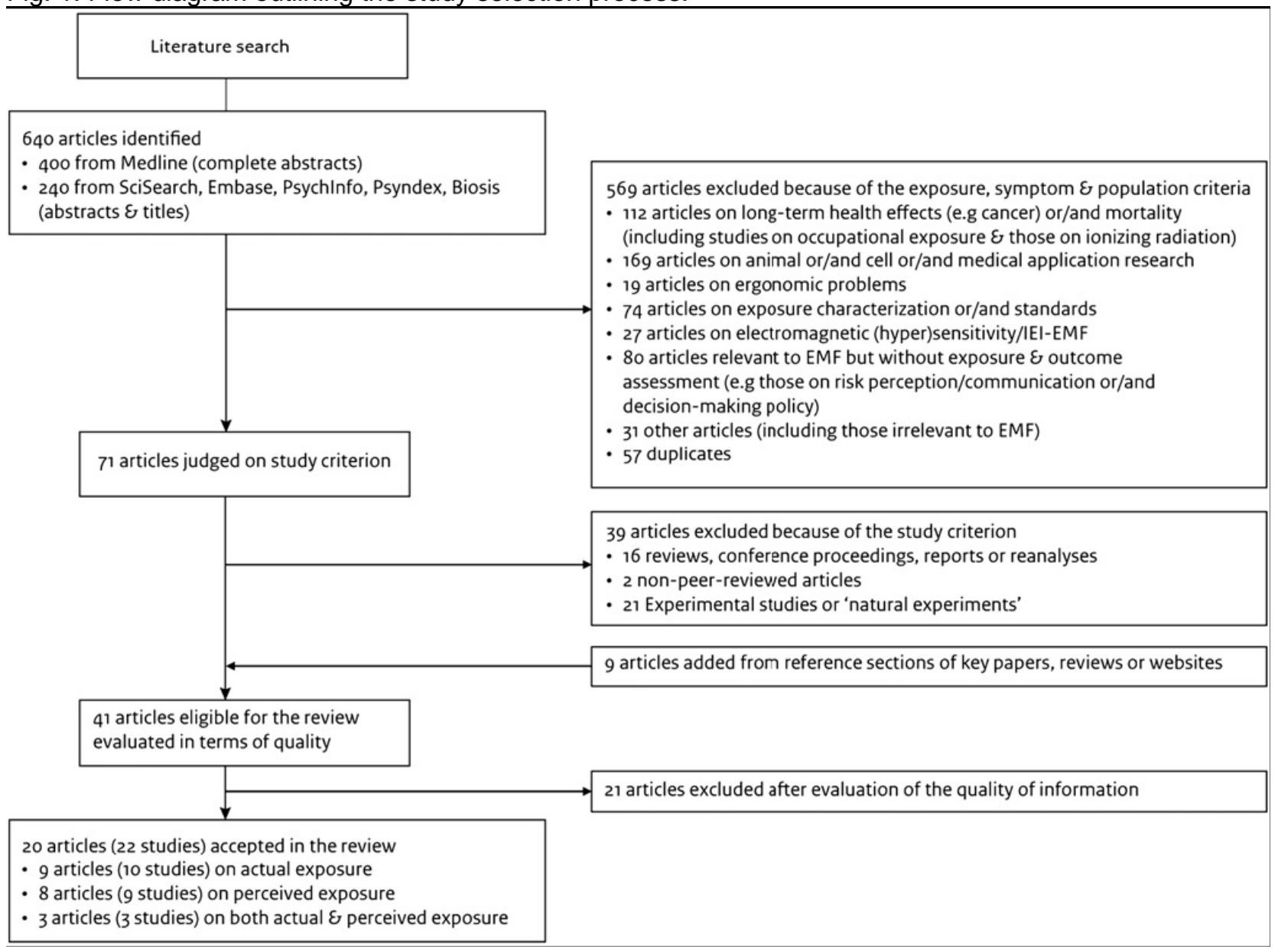

Table 5

Odds ratio of self-reported NSPS based on their severity (acute) and frequency (chronic), according to random-effect meta-analyses of observational studies on the association between actual EMF exposure and NSPS.

\begin{tabular}{|c|c|c|c|c|c|c|c|c|}
\hline Outcome & $\begin{array}{l}\text { Studies } \\
\mathrm{n}\end{array}$ & $\begin{array}{l}\text { Reference group } \\
n^{a}\end{array}$ & $\begin{array}{l}\text { Highly exposed group } \\
\mathrm{n}^{\mathrm{a}}\end{array}$ & $\begin{array}{l}\text { Combined OR } \\
(95 \% \mathrm{CI})\end{array}$ & $P$ & $\tau^{2}$ & $I^{2} \%$ & Egger's test $P$ \\
\hline \multicolumn{9}{|l|}{ Acute NSPS } \\
\hline Headache & 3 & 626 & 544 & $1.65(0.88-3.08)$ & 0.11 & 0.13 & 40.3 & 0.97 \\
\hline Concentration problems & 3 & 626 & 544 & $1.28(0.56-2.94)$ & 0.55 & 0.28 & 57.5 & 0.91 \\
\hline Fatigue-related problems & 3 & 626 & 544 & $1.15(0.59-2.27)$ & 0.66 & 0.23 & 66.7 & 0.78 \\
\hline $\begin{array}{l}\text { Dizziness-related problems } \\
\text { Chronic NSPS }\end{array}$ & 2 & 544 & 461 & $1.38(0.92-2.07)$ & 0.11 & 0.00 & 0.00 & N.A \\
\hline Headache & 2 & 459 & 460 & $1.01(0.66-1.53)$ & 0.96 & 0.00 & 0.00 & N.A \\
\hline Fatigue & 2 & 459 & 460 & $1.12(0.60-2.07)$ & 0.71 & 0.11 & 0.00 & N.A \\
\hline Sleep problems & 4 & 1248 & 649 & $1.18(0.80-1.74)$ & 0.40 & 0.03 & 24.7 & 0.28 \\
\hline
\end{tabular}

Note: OR, Odds ratio; CI, Confidence interval; $P$, p value, $\tau^{2}$, square tau value for heterogeneity; $I^{2}$, statistic for heterogeneity; Egger's test, Regression test for publication bias; N.A, not applicable due to limited number of analyzed studies.

a Data regarding the number of participants for the exposure categories are provided after personal communication with the original authors. 
Baliatsas, C., Kamp, I. van, Bolte, J., Schipper, M., Yzermans, J., Lebret, E. Non-specific physical sympton's and electromagnetic field exposure in the general population: can we get more specific? A systematic review Environment International: 2012, 41(1), 15-28

Fig. 2. Forest plots of random-effect meta-analyses of observational studies on the association between actual EMF exposure and NSPS for 4 self-reported outcomes based on severity.

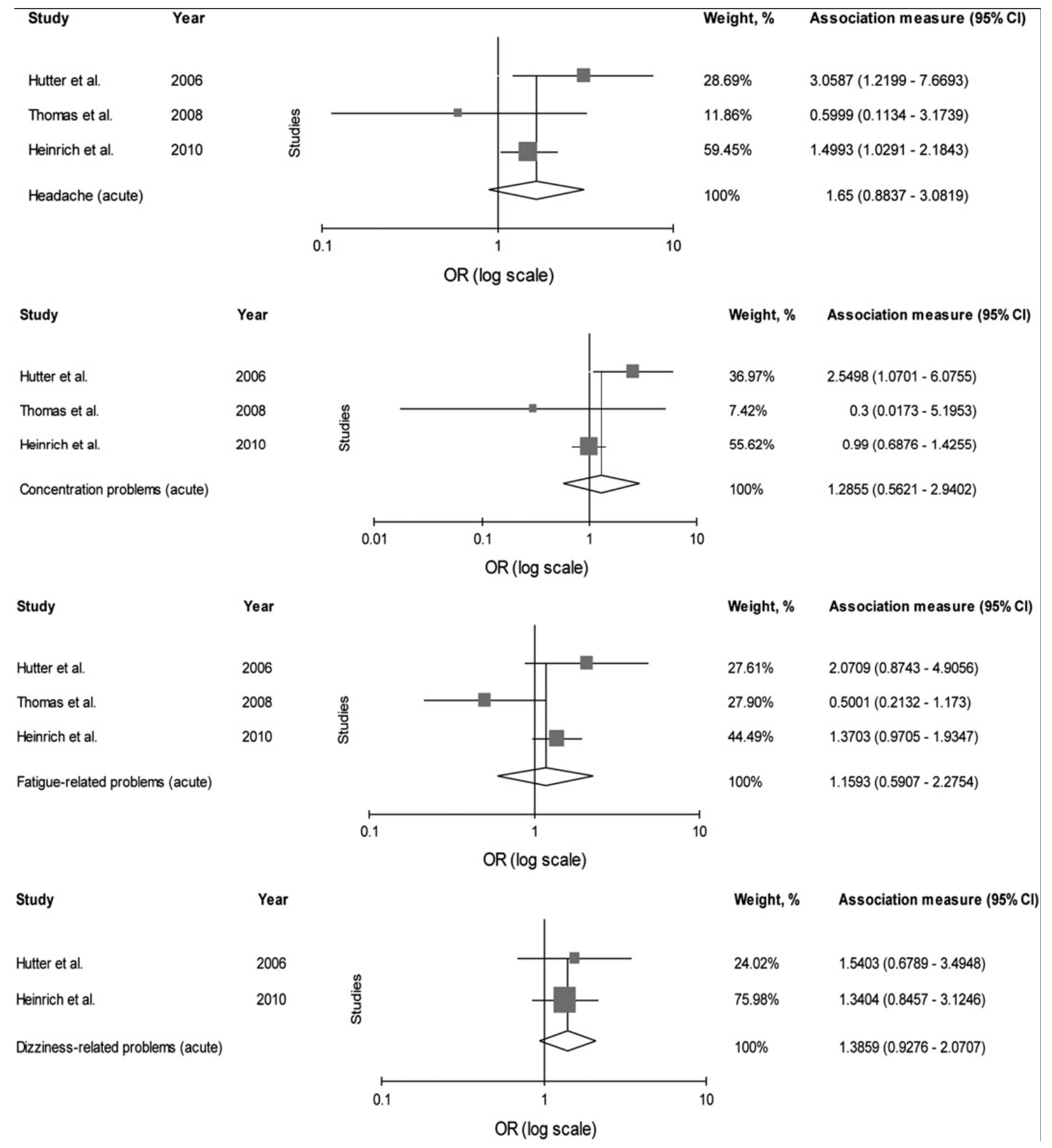


Baliatsas, C., Kamp, I. van, Bolte, J., Schipper, M., Yzermans, J., Lebret, E. Non-specific physical symptomis and electromagnetic field exposure in the general population: can we get more specific? A systematic review. Environment International: 2012, 41(1), 15-28

Fig. 3. Forest plots of random-effect meta-analyses of observational studies on the association between actual EMF exposure and NSPS for 3 self-reported outcomes based on frequency.

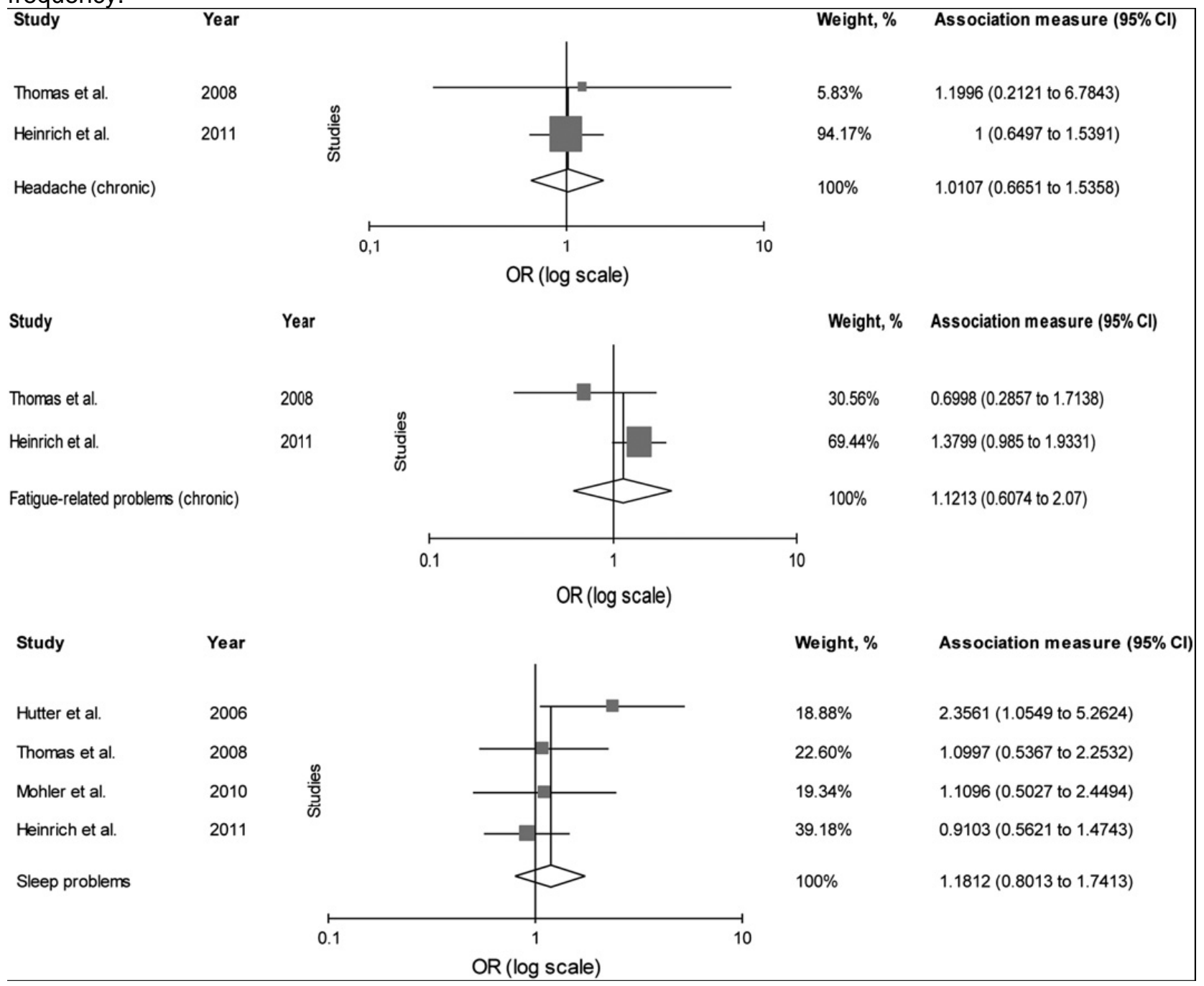


Baliatsas, C., Kamp, I. van, Bolte, J., Schipper, M., Yzermans, J., Lebret, E. Non-specific physical symptomis and electromagnetic field exposure in the general population: can we get more specific? A systematic review Environment International: 2012, 41(1), 15-28

\section{Appendix A. List of excluded articles (based on the evaluation of the quality of information) and reasons for exclusion}

\begin{tabular}{lll}
\hline Reference & $\begin{array}{l}\text { Exposure (based on the } \\
\text { assessment method) }\end{array}$ & $\begin{array}{l}\text { Primary reason(s) } \\
\text { for exclusion }\end{array}$ \\
\hline Santini et al., 2002 & Perceived & 1,2 \\
Navarro et al., 2003 & Perceived & 1,2 \\
Santini et al., 2003 & Perceived & 1,2 \\
Al-Khlaiwi and Meo, 2004 & Perceived & $1,2,3$ \\
Balikci et al., 2005 & Perceived & $1,2,3$ \\
Balik et al., 2005 & Perceived & $1,2,3$ \\
Meo and Al-Drees, 2005a & Perceived & $1,2,3$ \\
Meo and Al-Drees, 2005b & Perceived & $1,2,3$ \\
Szyjkowska et al., 2005 & Perceived & 1,2 \\
Al-Khamees, 2007 & Perceived & 1,2 \\
Davidson and Lutman, 2007 & Perceived & 1 \\
Koivusilta et al., 2007 & Perceived & 1 \\
Pennarola et al., 2007 & Perceived & 1,2 \\
Punamäki et al., 2007 & Perceived & 1 \\
Thomée et al., 2007 & Perceived & 1 \\
Al-Abduljawad, 2008 & Perceived & $1,2,3$ \\
Al-Khamees, 2008 & Perceived & $1,2,3$ \\
Khan, 2008 & Perceived & $1,2,3$ \\
Kucer, 2008 & Perceived & $1,2,3$ \\
Augner and Hacker, 2009 & Perceived & 1 \\
Eger and Jahn, 2010 & Actual & 1 \\
\hline
\end{tabular}

${ }^{*}$ Note: $1=\mathrm{No}$ (report of) adjustment for confounding variables, 2 = lack of important information regarding study design and/or sample recruitment/size/characteristics, $3=$ lack of important information regarding the methods/instruments that were used for the exposure and outcome assessment. 